\title{
Review on Molecular Epidemiology in Relation to Devastating Late Blight Pathogen, $P$. infestans, de Bary
}

\author{
Pranamika Sharma*, Anil Kumar Jena, Rimi Deuri, \\ Surya Prakash Singh and Sangeeta Sarmah
}

\author{
Department of Agriculture \& Horticulture, Arunachal University of Studies, Namsai, \\ Arunachal Pradesh, India \\ *Corresponding author
}

\begin{tabular}{|c|}
\hline Keywords \\
\hline $\begin{array}{l}\text { Molecular } \\
\text { epidemiology, } \\
\text { Etiolgy, } P \text {. } \\
\text { infestans, Late } \\
\text { blight, Marker }\end{array}$ \\
\hline Article Info \\
\hline $\begin{array}{l}\text { Accepted: } \\
\text { 26 July } 2018 \\
\text { Available Online: } \\
10 \text { August } 2018\end{array}$ \\
\hline
\end{tabular}

\section{Introduction}

Phytophthora infestans causes late blight on a range of solanaceous plant species and can devastate potato and tomato crops in most cool-temperate environments worldwide. Crop losses and costs of late-blight control constitute a significant financial burden on the potato industry. In many potato-growing areas, frequent fungicide applications are the main method of disease control. These applications commence when a local inoculums source is identified and/or
Molecular epidemiology is a science that focuses on the contribution of potential genetic and environmental risk factors, identified at the molecular level, to the etiology, distribution and prevention of disease Molecular epidemiology provides the 'tools' (both laboratory and analytical) that have predictive significance and that epidemiologists can use to better define the etiology of specific diseases, and work towards their control. Application of these molecular techniques has increased the understanding of the epidemiology of the most important infectious agents, Phytophthora infestans. Recent progress in $P$. infestans genomics is providing the raw data for such methods and new bio molecular markers are currently being developed which have tremendous potential in the study of $P$. infestans. Closer collaborations between specialists in the fields of plant pathology, epidemiology, population genetics / molecular ecology, $P$. infestans molecular biology and plant breeding are advocated to enable such progress. Molecular techniques help to stratify and to refine data by providing more sensitive and specific measurements which facilitate epidemiologic activities including disease surveillance, outbreak investigations, identifying transmission patterns and risk factors among apparently disparate cases characterizing host pathogen interactions and providing better understanding of disease pathogenesis at the molecular level.. 
resistance has the potential to replace at least some of the chemical inputs (Gans, 2003; Kessel et al., 2003). When released in the UK, the potato cultivars Pentland Dell and Maris Peer were highly resistant to late blight. Their resistance was, however, based on simple combinations of $\mathrm{R}$ genes and was overcome as the frequency of matching virulence genes in the $P$. infestans population increased (Malcolmson, 1969). This increase was as a direct result of the selection pressure imposed upon the pathogen population by the cultivation of these cultivars (Shattock et al., 1977) and illustrates the potential problems of relying on host resistance for disease control without due consideration of how the pathogen population may respond to its deployment. Similarly, the widespread use of the phenylamide class of systemic blight fungicides soon after their release drastically increased the frequency of resistant isolates (e.g. Dowley and O'Sullivan, 1985) resulting in failures in disease control (Bradshaw and Vaughan, 1996). Predicting the sustainability of disease-management strategies is clearly dependent on an understanding of the pathogen and its population dynamics. This is especially true of potato late blight, as $P$. infestans has been classified as 'high risk' based on its evolutionary potential (McDonald and Linde, 2002). Phytophothora infestans is thus a moving target and the bodies (e.g. advisors, forecasters, agrochemical companies, researchers, regulatory bodies, breeders, etc.) responsible for practical longand short term advice to the potato industry need data on contemporary pathogen populations. Fungi and oomycetes are the causal agents of many of the world's most serious plant diseases and are unique among the microbial pathogens in being able to breach the intact surfaces of host plants. Recently, there have been a number of studies published describing the genome sequences of a diverse set of fungi and oomycetes including one published in this issue of The Plant Cell
(Hane et al., 2007), and this provides an opportunity to review what we have learned so far from sequencing the genomes of pathogenic and free-living fungi and also to look forward to the mass of genome sequence information that is likely to be generated in the next few years. The deployment of low-cost, high-throughput DNA sequencing technologies and large-scale functional genomics to eukaryotic plant pathogens will provide new insight into their biology and into the evolution of pathogenicity. Phytophthora literally means plant destroyer, a name coined by Anton de Bary in 1861 when he proved that a microorganism, designated as a fungus, was the causal agent of a plant disease known as late blight of potato and was responsible for the Irish potato famine (Large 1940). The genus Phytophthora belongs to the oomycetes, a diverse group that includes both saprophytes and pathogens of plants, insects, fish, vertebrates and microbes. More than 150 years ago, the late blight pathogen Phytophthora infestans struck the Irish potato crop. Virtually the entire potato crop was wiped out in a single warm, wet week in the summer of 1846. In its aftermath over 1 million people died and another 2 million emigrated from Ireland.

Among the plant pathogenic oomycetes are more than 65 Phytophthora species, a hundred or more Pythium species, and a variety of obligate biotrophs, including downy mildews and white rusts (Agrios, 2005; Erwin and Ribeiro, 1996). They cause devastating diseases on numerous crops and have an enormous impact on agriculture. Fungal and oomycete plant pathogens occupy similar ecological niches. Yet the distinct evolutionary history of the two groups implies that their pathogenic behavior evolved independently and that convergent evolution has shaped the genomes of these two major groups of plant pathogen Only in recent years have genomes of eukaryotic plant pathogens been sequenced. The first one was 
Magnaporthe grisea, the rice blast fungus (Dean et al., 2005), and to date, a handful of draft genome sequences of fungal plant pathogens are available (Xu et al., 2006). Overall, the genome sizes of fungi do not exceed $40 \mathrm{Mb}$ and they are mostly haploid. In contrast, the genomes of oomycetes studied so far are all larger than $45 \mathrm{Mb}$ and often double that size or more and they are diploid (Judelson and Blanco, 2005; Kamoun, 2003). It is, therefore, not surprising that it took some time before oomycete genome projects got off the ground. Advances in software and sequencing technologies have resulted in a decrease in costs and a sharp increase in the number of ongoing eukaryotic genome sequencing projects, and fortunately, oomycete sequencing projects are also on the rise. One incentive for funding a Phytophthora genome sequencing project was the emergence of a mysterious disease threatening California oak trees. Phytophthora ramorum, the causal agent of Sudden oak death, was described as a species in 2001 (Werres et al. 2001), and only four years later,a draft sequence of its genome was available. Emotion and scientific rationale clashed. The Californians cried because their magnificent oak trees were dying and they wanted immediate action to solve the problem. But the scientists raised doubts about the value of sequencing the genome of a relatively unknown species that had no history of research and that few people studied. The compromise was to include a second species, Phytophthora sojae that, next to 'the Irish potato famine fungus' Phytophthora infestans, has the status of being a model for molecular genetic research on oomycetes. P.sojae was first described in the 1950s as the causal agent of root and stem rot on soybean (Hildebrand 1959; Kaufmann and Gerdemann 1958). Thus $P$. infestans and $P$. sojae each attack major food and feed crops and are devastating pathogens worldwide. Phytophthora infestans, (Mont.) de Bary is the causative agent of the late blight disease of tomato and potato and is by far the most devastating disease of potato worldwide (Fry and Goodwin, 1997b). P.infestans, which has caused the Irish potato famine in the mid nineteenth century (de Bary, 1876), continues to cause multi-billion dollar losses annually in potato and tomato production (Fry and Goodwin, 1997a; Fry and Goodwin, 1997b). The havoc that $P$. infestans wreaks on potato and tomato is yet to be effectively controlled, and the problem worsened with the recent emergence of highly aggressive and fungicide in sensitive strains (Fry and Goodwin, 1997a; Fry and Goodwin, 1997b). In fact, recent reports warned that potato blight might cause catastrophic losses, and possibly famine, in Eastern Europe, and recent epidemics in that region resulted in as much as $70 \%$ losses in yield (Schiermeier, 2001; Garelik, 2002). P. infestans belongs to a unique taxonomic group of organisms called the oomycetes. This group includes various plant and animal pathogens as well as saprophytic species (Margulis and Schwartz, 2000). Historically, based on their fungal-like morphology and physiology, the oomycetes have been referred to as fungi. Increasing biochemical (Bartnicki-Garcia and Wang, 1983; Pfyffer et al., 1990) and molecular (Paquin et al., 1997; Sogin and Silberman, 1998) evidence has shown that oomycetes are not fungi, but are more related to heterokont algae. Their unique phylogenetic position suggests that molecular mechanisms underlying host infection and interaction could be unique. Invariably, fungal pathogens, for which molecular studies are more advanced, cannot serve as models to study oomycetes. Also, in light of the different evolutionary history of the fungi, the unique biochemical features of oomycetes render them insensitive to many of the fungicides available (Griffith $e t$ al., 1992; Kirk et al., 1999). Effective management of diseases caused by the oomycetes, will come from a thorough understanding of the mechanisms underlying 
pathogenicity and plant responses to the pathogen and the development of specific fungicides. In this review, I discuss the life cycle of $P$. infestans, pathogenicity, elicitors and host/nonhost resistance, and finally I discuss recent genomic resources and functional genomic systems available for $P$. infestans.

\section{Phytophthora infestans infection cycle}

The $P$. infestans infection cycle is well known (Pristou and Gallegly, 1954: Coffey and Wilson, 1983; Agrios, 1988; Erwin and Ribeiro, 1996). Infection is initiated when sporangia come into contact with a moist leaf surface. The sporangia will either germinate directly at temperatures above $15^{\circ} \mathrm{C}$ or release biflagellate zoospores at temperatures below $15^{\circ} \mathrm{C}$. The motile biflagellated zoospores then germinate after encystment on the surface of the plant. Following appressorium formation, infection tubes emerge and penetrate epidermal cells. In susceptible plants (compatible interactions), hyphae spread into the mesophyll layer, occasionally forming haustorium-like feeding structures. After colonization, sporangiophores are formed at the tip of emerging hyphae from the stomata. These become inocula for subsequent aerial spread of the pathogen (Fig. 1 and 2). Infected foliage becomes yellow, water soaked and ultimately turns black. In resistant plants (incompatible interactions), a form of programmed cell death known as the hypersensitive response (HR) is induced. Cytological studies demonstrated that the hypersensitive response is associated with all forms of resistance to $P$. infestans, albeit at different rates of induction (Vleeshouwers etal., 2000). In race specific resistant hostplants, induction of the HR is limited to one or a few cells and results in the arrest of pathogen growth in the early stages of infection (Kamoun et al., 1999c; Vleeshouwers et al., 2000). Other types of resistance, such as partial or rate-limiting resistance, also involve the HR, which can occur as a trailing type of necrosis (et al., 1999c; Vleeshouwers et al., 2000) and in nonhost.

During the growing season, infections usually start from primary infected potato plants with sporangiophores carrying sporangia. These sporangia are wind dispersed and can start new infections in two ways. Under wet conditions and temperatures below $12 \mathrm{oC}$, sporangia develop into zoosporangia that release a number of zoospores, each carrying two flagella. After a mobile period, which can last for over ten hours, these zoospores stop moving and a thick cell wall is formed creating a cyst. Alternatively, at higher temperatures sporangia act as sporangiospores that can germinate directly. Both cysts and sporangiospores germinate and at germtube tip an appressorium is formed a specialized structure from which a penetration peg emerges that pierces the cuticle and penetrates the epidermal cell. In the epidermal cell an infection vesicle is formed from which the colonization of the underlaying cell layers starts. $P$. infestans grows in between the mesophyl cells where feeding structures (haustoria) are formed.

After three to four days with conditions favorable to the pathogen, hyphae emerge through the stomata and sporangiophores with sporangia are formed which can start a new cycle of infection. At this time the leaf can still look healthy, without clear symptoms, but more often part of the leaf becomes necrotic and may be surrounded by a white fluffy area where the plant tissue is covered by sporangiophores. $P$. infestans can infect leaves, stems, berries and tubers. While infected tubers are the most common source of inoculum at the beginning of the season (Zwankhuizen et al., 1998), infections can also start from oospores 
that result from the sexual cycle and can survive several years in the soil (FLIER et al. 2001b). The sexual cycle starts when vegetative hyphae of two opposite mating types (A1 and A2) meet. This induces the formation of oogonia and antheridia. The oogonium grows through the antheridium and after meiosis a fertilization tube grows from the antheridium through the oogonial cell wall and delivers the haploid antheridial nucleus into the oogonium. Subsequently, a thick cell wall is formed making oospores persistent structures. Germinating oospores can form a sporangium, which can start infection of tubers, stems and leaves.

\section{Molecular epidemiology: Focus on infection}

Molecular biology techniques have become increasingly integrated into the practice of infectious disease epidemiology. The term "molecular epidemiology" routinely appears in the titles of articles that use molecular strain-typing ("fingerprinting") techniquesregardless of whether there is any epidemiologic application. What distinguishes molecular epidemiology is both the "molecular," the use of the techniques of molecular biology, and the "epidemiology," the study of the distribution and determinants of disease occurrence in plant populations. This reviews various definitions of molecular epidemiology and comment on the range of molecular techniques available and present some examples of the benefits and challenges of applying these techniques to infectious agents and their affected host using tuberculosis and urinary tract infection as examples.They close with some thoughts about training future epidemiologists to best take advantage of the new opportunities that arise from integrating epidemiologic methods with modern molecular biology. Am J Epidemiol 2001;153: 1135-41. Molecular epidemiology provides the 'tools' (both laboratory and analytical) that have predictive significance and that epidemiologists can use to better define the etiology of specific diseases, and work towards their control (Andrew Thompson Molecular epidemiology of infectious diseases 2000. 326p). It is a science that focuses on the contribution of potential genetic and environmental risk factors, identified at the molecular level, to the etiology, distribution and prevention of disease. Over the past two decades, there has been a proliferation of subspecialties among epidemiologists. Perhaps none of these subspecialties has been received with more controversy than "molecular epidemiology," as the term "molecular" describes neither a disease category nor a substantive area (1) but in jargonese refers to characteristics based on nucleic acid- or amino acid-based content. The issue is further confused by the independent emergence of the term molecular epidemiology during the 1970s and early 1980 s in three separate substantive areas: cancer epidemiology, environmental epidemiology, and infectious disease epidemiology. In many epidemiologic textbooks, molecular epidemiology has been defined almost exclusively in terms of biomarkers (2), ignoring the many applications in both genetic and infectious disease epidemiology

\section{What exactly is molecular epidemiology?}

Many different definitions of molecular epidemiology have been published all mention the use of molecular tools, but not all explicitly mention epidemiology. This is unfortunate, as molecular epidemiology is not just molecular taxonomy, phylogeny, or population genetics but the application of these techniques to epidemiologic problems. Molecular taxonomy, phylogeny, population genetics, and molecular epidemiology may use the same laboratory techniques, but each follows distinct principles. In phylogeny/ taxonomy, the data are generated to describe 
properties and characteristics of organisms. Population genetics often intersects with epidemiology: both use population approaches to describe the distribution of characteristics of interest and analyze data to identify the determinants of that distribution. Epidemiology attempts to identify factors that determine disease distribution in time and place, as well as factors that determine disease transmission, manifestation, and progression. Further, epidemiology is always motivated by an opportunity or possibility for intervention and prevention. What distinguishes molecular epidemiology is both the "molecular," the use of the techniques of molecular biology to characterize nucleic acid- or amino acid-based content, and the "epidemiology," the study of the distribution and determinants of disease occurrence in human populations.

\section{Various definitions of molecular epidemiology}

"The application of sophisticated techniques to the epidemiologic study of biological material"

"Molecular epidemiology is the use of biologic markers or biologic measurements in epidemiologic research"

"The application of molecular biology to the study of infectious disease epidemiology"

"Using molecular biomarkers in epidemiology"

"Molecular epidemiologic research involves the identification of relations between previous exposure to some putative causative agent and subsequent biological effects in a cluster of individuals in populations"

"The analysis of nucleic acids and proteins in the study of health and disease determinants in human populations"
"Molecular epidemiology uses molecular techniques to define disease and its preclinical states, to quantify exposure and its early biological effect, and to identify the presence of susceptibility genes"

"The practical goals of molecular epidemiology are to identify the microparasites responsible for infectious diseases and determine their physical sources, their biological relationships, and their route of transmission and those of the genes responsible for their virulence, vaccine relevant antigens and drug resistance"

"A science that focuses on the contribution of potential genetic and environmental risk factors, identified at the molecular level, to the etiology, distribution and prevention of disease".

\section{Molecular techniques}

Molecular techniques do not substitute for conventional methods. They address epidemiologic problems that cannot be approached or would be more labor intensive, expensive, and/or time consuming to address by conventional techniques. Today's molecular technique can become tomorrow's conventional diagnostic tool or even consigned to the wastebasket. For example, plasmid profile analysis was a mainstay of molecular fingerprinting just a short while ago and now has been almost entirely replaced by other techniques. Acknowledging that any list of molecular techniques will be outdated from the time it is published, and the techniques that have been applied in epidemiologic studies of infectious disease. They fall into two large categories: identification and fingerprinting (strain typing). Rather than describe the techniques themselves in detail, we describe how the application of some of these techniques has increased our 
understanding of the epidemiology of two important infectious agents: Mycobacterium tuberculosis, which causes tuberculosis, and uropathogenic Escherichia coli, which causes urinary tract infection. Tuberculosis is the most common infectious cause of deaths in adults worldwide (3), and urinary tract infection is one of the most common bacterial infections, affecting half of all women (4) and one seventh of all men at least once during their lifetime (5). We will use these pathogens to illustrate the distinct approaches and principles that must be considered when conducting epidemiologic investigations using molecular technics. Molecular techniques are used to study and solve the epidemiological problems that the traditional epidemiological methods can not.

\section{Basic molecular markers used in molecular epidemiology}

\section{Individual (Molecular diagnosis):}

1. Hybridization,

2. PCR-based:
a. classical PCR,
b. nested PCR,
c. real-time PCR.

\section{Population}

1. PCR-based assay: RAPD, ISSR (internal simple sequence repeat, MP-PCR), AFLP.

2. Hybridization RFLP.

3. DNA sequence: ITS, IGS, Protein genes- $\beta$ tubulia, EF1 $\alpha$, Elongation factor.

Evolution is an important factor in predicting the effectiveness and durability of new management practices. A range of phenotypic and genotypic tests has been applied to achieve this goal, but each has limitations and new methods are sought. Recent progress in $P$. infestans genomics is providing the raw data for such methods and new high-throughput codominant biomolecular markers are currently being developed that have tremendous potential in the study of $P$. infestans population biology, epidemiology, ecology, genetics and evolution. This reviews some key applications, recommends some changes in approach and reports on the status and potential of new and existing methods for probing $P$. infestans genetic diversity of information familiar to plant pathologists concerning the aetiology and epidemiology of the disease; for example, understanding the origins of disease outbreaks on both local (e.g. individual seed tubers, dumps, soilborne oospores) and international (e.g. global seed trade or large-scale weather systems) scales. However, a greater understanding of the biology of $P$. infestans infection, genetics, genomics and evolutionary processes is also important. There must be a greater emphasis on $P$. infestans. Understanding the relative contributions and rates of mutation, recombination, natural selection, gene flow, random genetic drift and migration (Burdon and Silk, 1997) to the generation and maintenance of variation in populations is important, yet such factors remain little studied (McDermott and McDonald, 1993) and poorly understood. Similarly, the paucity of information on the below-ground and soilborne phases of the disease, the absence of a widely adopted and objective means of estimating $P$. infestans population diversity and a lack of understanding of the impact of selection pressure are also hampering scientific progress. Recent advances in $P$. infestans physical (Randall and Judelson, 1999; Whisson et al., 2001) and genetic (van der Lee et al., 1997) mapping, genomics (Kamoun et al., 1999; Birch and Whisson, 2001; Birch et al., 2003; Bos et al., 2003), and the functional analysis of genes involved in growth, development and plant infection (Birch and Kamoun, 2000; Avrova et al., 2003; Torto et al., 2003) are revolutionizing 
the field of Phytophthora research. They also form a crucial resource from which valuable DNA-based markers can be generated and this, coupled with advances in fingerprinting technology and laboratory automation, is facilitating affordable, high-throughput analysis of multiple DNA-based markers. It is therefore timely to review the types and likely contributions of such biomolecular markers in advancing $P$. infestans research in key fields such as population biology, epidemiology, genetics and the mapping and functional analysis of novel genes. In light of the threats from changing $P$. infestans populations in many regions worldwide (Fry and Goodwin, 1997), particular emphasis will be placed on the utility of existing phenotypic and genotypic markers and the potential of new methodology for examining $P$. infestans populations. It is suggested that new methods and approaches are needed to stimulate advances in this field.

\section{The applications of marker technology}

It is clear that no single marker system (Milbourne et al., 1997) will be adequate for all aspects of $P$. infestans research. This review firstly considers the principal applications of new marker technology, examining the requirements of each type of study. Some key considerations in selecting an appropriate marker are depth of taxonomic resolution, run-in time and resources available, throughput required, running costs and proposed adaptation by other research groups.

\section{Population diversity and population genetics}

Probably the most common objective in the study of $P$. infestans populations is to ensure that management practices, prediction tools and potato breeding strategies are appropriate for the contemporary pathogen population.
The monitoring of $\mathrm{A} 1$ and $\mathrm{A} 2$ mating-type ratios is important to aid predictions of the extent of sexual recombination and thus the risk of long-lived oospores serving as primary inoculum sources. In addition to its epidemiological impact, sexual recombination is likely to increase the rate of pathogen adaptation (Barton and Charlesworth, 1998), thus reducing the predictability of disease management practices. Understanding the population biology of $P$. infestans and closely related taxa (e.g. $P$. phaseoli, $P$. ipomoeae and $P$. mirabilis) in 'natural' ecosystems and comparing it with populations on cultivated crops are

Characteristics of an ideal marker system for the genetic analysis of Phytophthora infestans

High throughput uses the most widespread and affordable technology available (e.g. PCR), capable of being multiplexed (i.e. several traits can be analysed simultaneously within a single isolate), robust, optimized protocols for running and objective scoring of the assays to encourage widespread adoption of a standard marker system, flexible, can be applied to both pure $P$. infestans DNA samples and infected leaf material or spore washings, can be modified to the resolution appropriate to the study, e.g. from the study of closely related species to intrapopulation diversity, suitable for rigorous genetic analysis. Markers unlinked, simply inherited and, ideally, mapped to each linkage group codominant (both alleles at a locus revealed). A combination of nuclear and mitochondrial targets, broadly applied, widely disseminated protocols resulting in its universal adoption, safe, does not involve hazardous procedures or chemicals. It is important to distinguish between studies of population diversity and population genetics; the former yield the raw data, to which the latter can be applied to answer questions on the fundamental 
mechanisms and processes of genetic change in populations (reviewed in Milgroom and Fry, 1997). Surveys are conducted by collecting isolates that represent a 'snapshot' of the overall population in time and space.

Temporal and geographic variations in phenotypic and/or genotypic diversity are then examined and interpreted in relation to the scientific goals of the study. There are many examples of this type of study in which the sophistication of the analysis has advanced from phenotypic (Malcolmson, 1969; Shattock et al., 1977) to genotypic methods, such as analysis of isozymes (Shattock et al., 1986; Tooley et al., 1985), mtDNA and RG57 restriction fragment length polymorphism (RFLP) patterns (Goodwin et al., 1994), amplified fragment length polymorphisms (AFLPs) (Cooke et al., 2003; Flier et al., 2003) and, more recently, simple sequence repeats (SSRs) (Knapova and Gisi, 2002). With the exception of the already diverse populations at its centre of origin (Goodwin et al., 1992a), an overall trend of increasing diversity in $P$. infestans has been observed in many potato-growing regions of the world. Early studies described populations that were clonal or dominated by a few discrete lineages (Drenth et al., 1994; Goodwin et al., 1998; Cohen, 2002), whereas more recent analysis highlights the appearance of many new genotypes via migration and sexual recombination (e.g. Sujkowski et al., 1994; Goodwin et al., 1995a, 1998; Punja et al., 1998; Hermansen et al., 2000; Cooke et al., 2003). Evaluating the evolutionary forces driving such population change and the practical significance to disease control remains difficult (Goodwin, 1997). Comparing regional studies to build up an international perspective of $P$. infestans population dynamics would be beneficial, but unfortunately has not proved possible. In part, the problem stems from the logistical difficulties of comparing data collected in different laboratories, but a more serious problem is the nature of the raw data. Mating type, RG57 loci and isozyme data have been central in elucidating the movement and displacement of major lineages (Goodwinn et al., 1994) and data from more than 1500 isolates have yielded a valuable baseline description of the dominant lineages in many countries (Forbes et al., 1998). However, the data are not appropriate for the type of powerful population genetic analysis needed to critically examine $P$. infestans populations on this scale. There is a clear need for both new markers and a new approach to interpreting fluxes in $P$. infestans populations.

The practical criteria that will encourage the uptake of any new marker and those necessary to ensure the data are appropriate for population genetic analysis. In terms of practicality, the methods should use commonly available technology, and be based on cost effective, high-throughput, robust and freely available detailed protocols to ensure their widespread adoption. Population genetic analysis is typically based upon five to 15 unlinked, simply inherited and codominant markers (Harper et al., 2003; Maggioni et al., 2003; Chauvet et al., 2004).

Codominance, meaning both alleles at a locus can be unambiguously resolved, is particularly important as it allows a more robust and powerful population genetic analysis. It is critical that new markers are appropriate for comparison of isolates both within and between populations on local and intercontinental scales and can accommodate the problem of convergence while adequately describing the ever-expanding genotypic diversity. Convergence (or homoplasy) occurs when isolates of different genetic backgrounds share an identical fingerprint. Such apparent 'identity' occurs by chance alone, rather than common descent, and will confound genetic analysis. 
AFLP (amplified fragment length polymorphisms

1.Genomic DNA is digested with both a restriction enzyme that cuts frequently (MseI, 4 bp recognition sequence) and one that cuts less frequently (EcoRI, 6 bp recognition sequence).

2.The resulting fragments are ligated to endspecific adaptor molecules.

3.A preselective PCR amplification is done using primers complementary to each of the two adaptor sequences, except for the presence of one additional base at the 3 ' end. Which base is chosen by the user. Amplification of only 1/16th of EcoRI-MseI fragments occurs.

AFLP fingerprinting, for example, discriminates isolates considered identical based on RG57 fingerprint (Purvis et al., 2001) and two SSR markers (Knapova and Gisi, 2002). The converse, where a high proportion of isolates within a population have unique genetic fingerprints (e.g. Brurberg et al., 1999; Zwankhuizen et al., 2000; Cooke et al., 2003), results in an endlessly expanding list of defined genotypes. The currently adopted system of designating genotypes (Goodwin et al., 1994; Forbes et al., 1998) is based on a country code followed by a unique number for each new genotype, with subcategories for isolates presumed to have emerged within a genotype. As a growing feature of $P$. infestans populations is a 'blurring' of the boundaries of genetically distinct subpopulations, the number of genotypes that need to be described in this way is likely to increase exponentially and, in the longer term, this may not be a helpful approach. There are now many variants of the US1 lineage (e.g. Forbes et al., 1998; Reis et al., 2003) and at least 19 'US' genotypes, some probably generated as recombinants of existing lineages (e.g. Gavino et al., 2000;
Wangsomboondee et al., 2002). An accepted naming system is clearly needed for dominant subgroups of the population (i.e. asexual lineages), but it needs to be able to accommodate this increasing diversity. A possible solution is a population approach in which the genotype of each new isolate is examined in the context of allele types, combinations and frequencies in series of populations hierarchically sampled at geographic scales ranging from a single leaf to a continent and, ideally, duplicated over time. Analysis using $F$-statistics (Hartl and Clark, 1997) and genetic distances (Goldstein and Pollock, 1997) yields detailed objective descriptions of the population structure and the relatedness of different subgroups. Other methods are applied to estimate effective population size, demographic history and the magnitude and direction of gene flow between populations (Hartl and Clark, 1997). Such accurate partitioning of genetic diversity will, for example, allow a critical examination of whether any new genotype is a subset of the local population (i.e. is derived from sexual recombination within the population) or is the result of migration, a novel mutation or recombination between populations. An international database of isolates genotyped using similar protocols. Markers for examining Phytophthora infestans is crucial to this approach. Linking existing and new population-based systems of nomenclature will be a major challenge, but will answer many key questions on the historical and contemporary patterns of migration of $P$. infestans; for example, what is the relationship between the US lineages and the populations currently dominant in Europe? Phytophthora infestans populations are characterized by patchiness and high rates of extinction and recolonization from one season to the next (Fry et al., 1992). Such a metapopulation structure means that small-scale sampling in a single season is unlikely to yield a true picture of the population structure. More extensive 
sampling over time and space is needed and sample throughput is therefore important for any new marker system. The direct testing of sporangia from sporulating lesions without lengthy isolation procedures is an obvious way to increase throughput, particularly if key phenotypic tests can be converted into reliable molecular assays (see below). Another crucial means of achieving this scaled-up approach is the coordination of research groups involved in the study of $P$. infestans. The recent EUfunded Concerted Action project EUCABLIGHT (http://www. eucablight.org) aims to develop, harmonize and disseminate protocols and data on $P$. infestans populations within Europe and, in the longer term, worldwide. As stated, the most powerful analysis tools rely on codominant data in which allele frequencies and distributions can be monitored over time.

\section{RFLP (restriction fragment length polymorphisms}

- Use the restriction endonucleases to recognize the specific DNA sequences.

- Hybridize to probe DNA or amplify by PCR.

- Analyze the variation of amplified bands.

\section{Real time PCR}

(1) Forward and reverse primers are extended with Taq polymerase as in a traditional PCR reaction. A probe with two fluorescent dyes attached anneals to the gene sequence between the two primers.

(2) As the polymerase extends the primer, the probe is displaced.

(3) An inherent nuclease activity in the polymerase cleaves the reporter dye from the probe.

(4) After release of the reporter dye from the quencher, a fluorescent signal is generated. SSR-PCR (Simple sequence repeats)

Bands are generated by a primer of simple sequence repeats. SSRs offer the greatest combination of required attributes for population analysis and their potential should be explored more fully. The increasing use of such biomolecular markers has great potential, but a move away from simply cataloguing $P$. infestans variation and towards experiments with sampling strategies designed to test specific hypotheses, using such markers within a theoretical framework of population genetics, is needed. In the coming years, the tracking of allele frequencies and distributions over time will advance the understanding of the spatial and temporal dynamics of $P$. infestans populations, as well as helping to estimate gene flow and investigate the balance between the forces of natural selection and chance effects of genetic drift and migration. From these data, the processes driving population change and how it may best be managed to the benefit of long-term disease control can be considered. For this to be realized, a coordinated approach is needed, in which the strengths of the disciplines of plant pathology, population genetics, molecular ecology and epidemiology are combined.

\section{Tracking isolates in epidemiological studies}

A major goal of the population analyses detailed above is to infer the processes driving population change. The resultant hypotheses based on such 'observational' survey data will, however, require rigorous testing. Such testing is not easy; even the suggestion that 'new' genotypes have replaced 'old' types in the UK because of increased aggressiveness has proved surprisingly difficult to test experimentally (Day and Shattock, 1997). Empirical data are needed from which the relative fitness of different strains can be compared directly. High-throughput markers 
will facilitate rapid isolate discrimination and thus direct comparisons of the frequency of recovery of two or more preselected isolates during the course of field epidemics. A single genetic marker that discriminates the test strains would be sufficient, offering a higher throughput than equivalent studies based on allozymes (Legard et al., 1995; Lebreton et al., 1999). Direct fingerprinting of Plasmopara Viticola lesions has been demonstrated (Gobbin et al., 2003) and work at SCRI showed that sporangia harvested from a single lesion or even single sporangia grown for a few days in a small volume of pea broth in a 96-well microplate yielded sufficient DNA for rapid PCR fingerprinting (Hussain, 2003). Fingerprinting using a more comprehensive range of markers also has potential for larger-scale tracking of isolates with specific traits. For example, understanding the origin and spread of strains that have overcome novel host resistance, or developed resistance to an important fungicide, is fundamental to managing the risk that such strains pose. Such isolate tracking can also be used effectively to determine sources of primary inoculum (Zwankhuizen $e t$ al., 2000). The association between seedborne infection and subsequent field outbreaks, for example, is important to the understanding of infection pathways and control methods, as well as having commercial and regulatory implications. Similar approaches have been used to identify source populations in the surveillance of human pathogens (Fisher et al., 2002). Tracking of inoculum using powerful genetic markers will also add detail to the fascinating palaeogeographical reconstruction of the spread of $P$. infestans across the world (Ristaino et al., 2001) and may influence international quarantine issues in the context of contemporary pathogen movement. SSRs offer the greatest potential for studies of comparative fitness, as multiple combinations of alleles are possible at each specific locus, thus increasing the likelihood of identifying unique test isolates for any given experiment. For tracking particular strains, or monitoring inoculums movement on a larger scale, SSRs again have the greatest potential to uniquely discriminate each strain. However, further work is needed to investigate whether the resolution offered by SSRs will be sufficient in populations with limited genetic diversity. If the specific mutation responsible for the change in phenotype is known, as in the case of QoI resistance in P. viticola (Gisi et al., 2002), the combined tracking of both selectable and neutral markers will yield the most useful data.

\section{Genetic mechanisms}

Phytophthora has a tremendous range of mechanisms for creating and maintaining genetic diversity (Brasier, 1992). However, the contribution of each mechanism to its adaptability under natural conditions remains poorly understood (Goodwin, 1997; Judelson, 1997b).

In addition to conventional genetic recombination of $\mathrm{A} 1$ and $\mathrm{A} 2$ mating types, self-fertility (Smart et al., 1998), segregation of heterokaryons (Pipe et al., 2000), zoosporemediated hyphal fusion (Judelson and Yang, 1998), mitotic recombination (Goodwin, 1997), polyploidy (Tooley and Therrien, 1991) and aneuploidy (Carter et al., 1999) have all been reported in $P$. infestans. Phenotypic variation during clonal reproduction (Caten and Jinks, 1968; Judelson, 1997a; Abu-El Samen et al., 2003) also remains poorly understood. Many phenotypic or genotypic markers have been used in the analysis of the above mechanisms, but a collection of well-characterized, PCRbased, codominant and, ideally, mapped markers such as single nucleotide polymorphisms (SNPs) or SSRs would be of great benefit in resolving such processes and their relative importance. 


\section{Mapping and functional analysis of genes}

The isolation of genes responsible for key traits, such as avirulence, pathogenicity, fungicide resistance or mating type, is an important target in $P$. infestans research (Judelson, 1997b; Birch et al., 2003; Kamoun, 2003). Positional, or map-based, cloning approaches rely on a high density of mapped markers in a segregating population and, in the absence of genomic resources, randomly generated AFLPs and RAPDs proved the most appropriate markers (Judelson et al., 1995; van der Lee et al., 1997, 2001).RAPD (Randomly amplified polymorphic DNA)) Bands are generated by a 10-bp Operon primer.
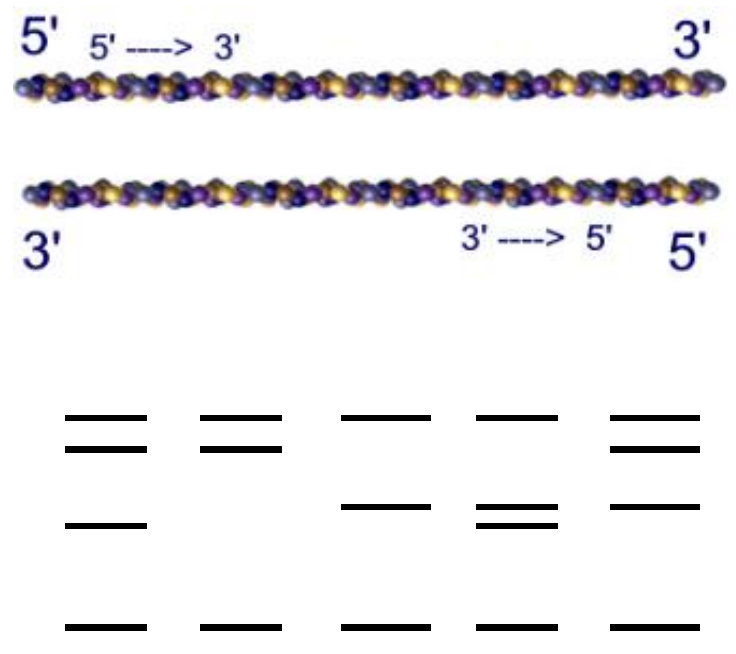

Three of the bands in the diagram are RAPD bands, and there are 5 polymorphic phenotypes

There is an urgent need for a genome-wide set of high-density markers in $P$. infestans to aid gene discovery and allow approaches such as 'natural selection mapping' to be applied. Unique patterns of linkage disequilibrium were recently confirmed around the region responsible for warfarin resistance in natural rat populations under a strong selection pressure (Kohn et al., 2000). Such an approach could be used in $P$. infestans to identify key fitness-related genes. Whether the candidate gene is identified by the above methods or comparative genomics (Bos et al., 2003), a first step towards confirming its function requires genetic markers either tightly linked to or within the gene. Association genetics can then be used to examine the correspondence of the phenotypic trait and the linked marker in multiple isolates from natural populations or progeny from test crosses. Clearly, marker position is critical for such analysis and SNPs are likely to be the most valuable markers as they occur at a high frequency (Brumfield et al., 2003) and can precisely target the specific nucleotide responsible for the amino acid change (e.g. Bos et al., 2003).

\section{The importance and potential of phenotypic markers}

Like most Phytophthora species, there are relatively few reliable morphological characters by which to discriminate $P$. infestans isolates (Shaw, 1991; Shaw and Shattock, 1991). The most studied of these phenotypic traits, and those that remain most informative, are mating type (Gallegly and Galindo, 1957), virulence (Malcolmson and Black, 1966) and fungicide resistance (Dowley and O'Sullivan, 1981).

\section{Mating type}

Studying the spatial and temporal distribution of the A1 and A2 strains of P. infestans is fundamental to understanding the significance of mating type to both the generation and maintenance of genetic diversity and to disease aetiology. Considerable efforts have therefore been made to estimate mating-type frequencies in $P$. infestans populations worldwide (Hermansen et al., 2000; Zwankhuizen et al., 2000; Cooke et al., 2003). Apart from the complication of self-fertility (Judelson, 1997a), the mating-type assay, 
based on the pairing of an unknown isolate with known tester A1 and A2 strains and screening for oospore production, is robust and reliable. However, an axenic culture of each isolate is required, which can be a bottleneck in the screening process. A reliable molecular assay for mating type would be valuable, but the genetic bases of mating-type determination are not yet fully understood and non-Mendelian segregation and frequent rearrangement in the region encoding the mating type loci (Judelson, 1997a) will make the design of the assay challenging.

\section{Virulence}

Genetic analysis of the resistance introgressed into Solanum tuberosum from wild Solanum species demonstrated a gene-for-gene interaction with single $\mathrm{R}$ genes in the host and corresponding virulence genes in the pathogen (Malcolmson and Black, 1966). An isolate's 'race', or virulence phenotype, is determined by inoculating a series of 11 genetically defined 'differential' potato genotypes, each carrying a specific $\mathrm{R}$ gene, then scoring the resultant compatible or incompatible reactions. The breakdown of Rgene- based resistance in cvs Pentland Dell (R1, R2, R3) and Maris Peer (R1, R2) prompted studies on how R-gene deployment may drive changes in the frequency of specific virulences in the pathogen population (Malcolmson, 1969; Shattock et al., 1977). Virulence has been monitored ever since and alongside an overall increase in virulence complexity with increasing sexual recombination (Drenth et al., 1994; Cohen, 2002), marked temporal and spatial variation in virulence has been reported (Lebreton and Andrivon, 1998; Peters et al., 1998; Hermansen et al., 2000). The emergence of virulence against all $11 \mathrm{R}$ genes in a clonal lineage (Goodwin et al., 1995b) and the variation in virulence types in singlezoospore progeny of a single isolate (Abu-El Samen et al., 2003) indicate that there is still much to learn about the generation and inheritance of virulence. It must also be acknowledged that additional $\mathrm{R}$ genes exist (Trognitz, 1998) and differential sets should be continually updated to accommodate them. Potential inconsistencies in virulence scores arise from variation in the differential sets used in different laboratories and the sensitivity of such assays to environmental conditions or changes in protocol (Stewart, 1990). The reduced use of R-gene-based resistance and the paucity of information on the $\mathrm{R}$ genes present in commonly grown cultivars make the interpretation of the evolutionary forces driving changes in specific virulence difficult. Furthermore, different genetic mutations may result in identical virulence phenotypes. The isolation of the specific avirulence effector genes ( $A v r$ genes) from $P$. infestans is, however, a major goal of many research programmes (van der Lee et al., 2001; Bos et al., 2003) and once the polymorphisms have been identified, specific DNA-based assays will be available. The combination of markers for such functional genes and neutral markers will be a powerful means of testing contemporary theories in host pathogen specificity. The 'guard hypothesis' (Dangl and Jones, 2001) proposes that a complex of the pathogen $A v r$ gene product with a plant virulence target is recognized by an $\mathrm{R}$ gene product. Implicit in this is that the Avr gene products themselves play a role in pathogenicity. Mutation to a statethat avoids host recognition (i.e. virulence) will, in the absence of that $\mathrm{R}$ gene, impose a 'fitness cost' on the pathogen. It is proposed that the opposing forces of fitness costs for resistance in the plant and virulence in the pathogen result in frequency-dependent balancing selection that maintains the alleles in both host and pathogen populations (Van der Hoorn et al., 2002). A cost of plant resistance has been demonstrated (Tian et al., 2003), and the specific tracking of different $A v r$ allele frequencies in natural or experimental 
populations will be critical in determining whether a corresponding 'fitness cost' to virulence exists. This hypothesis needs to be tested to predict the longevity of engineered resistance based on the pyramiding of $R$ genes.

\section{Fungicide resistance}

Fungicide resistance testing has, with the exception of routine testing within the agrochemical industry, predominantly targeted the well-documented resistance to phenylamides (reviewed in Gisi and Cohen, 1996). Agar-based (Shattock, 1988) or in vivo testing of many isolates (e.g. Dowley and Sullivan, 1985; Dowley et al., 2002) has indicated clear fluctuations in the frequency of resistant strains according to the fungicide deployment strategy (Davidse et al., 1981). It is unclear whether the reduced frequency of resistant strains, in response to reduced phenylamide use, is the result of random genetic drift to a low but stable level of resistance (Gisi and Cohen, 1996) or a fitness cost to metalaxyl resistance (e.g. Day and Shattock, 1997; Dowley et al., 2002). Again, the development of DNA-based assays, either within or linked to the genes conferring resistance, would be beneficial. However, the genetic basis of resistance is not fully understood (Shattock, 1988; Shaw, 1991; Lee et al., 1999) as it is likely that multiple loci are involved (Judelson and Roberts, 1999) and no reliable DNA-based assay for fungicide resistance is available. Limited study of the sensitivity of $P$. infestans to protectant fungicides revealed no marked variation (Kato et al., 1997). Resistance to the recently released QoI (quinine outside inhibitors) group of fungicides has been reported in cereal fungal pathogens and the oomycetes $P$. viticola and Pseudoperonospora cubensis (Ishii et al., 1999; Gisi et al., 2002). With the release of QoI fungicides for late blight control, active resistance monitoring in the commercial sector is ongoing. The mode of action and specific mutation to resistance has been located in the mitochondrial cytochrome $b$ gene (Gisi et al., 2002) and monitoring of this specific allele in $P$. infestans may be of interest.

\section{Other phenotypic characters}

Variation in other phenotypic characters has been tested on a limited scale. Differences in aggressiveness have been cited as an explanation for population displacements (Day and Shattock, 1997; Kato et al., 1997). Aggressiveness is a multicomponent trait and since many factors may affect infection efficiency, lesion size, incubation period, latent period and sporulation capacity (Spielman et al., 1992), it is a difficult character to measure objectively. Ploidy levels (Tooley and Therrien, 1991) and antibiotic resistance (Shattock and Shaw, 1975) have also been examined. Temperature response, which has important implications for decision support systems, has also been shown to vary amongst different populations (Mizubuti and Fry, 1998), but none of these characteristics has been systematically tested.

\section{The importance and potential of genotypicmarkers}

Whilst phenotypic traits are important for understanding the selection pressures on $P$. infestans populations, in isolation they do not fulfil many of the criteria in many different genotypic markers have been used to study $P$. infestans and here the status and future applications of each are considered.

\section{Isozymes}

Before the development of DNA-based molecular methods, isozyme variation was used extensively (Tooley et al., 1985). Isozyme data continues to provide valuable 
insights into the genetics (Shattock et al., 1986) and population diversity of $P$. infestans (Sujkowski et al., 1994) and was integral to the international naming system (Forbes et al., 1998). Isozymes are based on affordable technology and are codominant, yielding data amenable to population genetic analysis (Goodwin, 1997). However, of the many isozymes tested, only glucosephosphate isomerase and peptidase have proved suitable for widespread use (Spielman et al., 1990; Fry et al., 1992). Furthermore, despite improvements introduced with the celluloseacetate method (Goodwin et al., 1995c), isozymes fulfil few of the requirements of an ideal marker system. For example, migration distance is expressed in relative terms and can be difficult to interpret, a different stain is required for each enzyme, the precise nature of the genetic change that alters migration distances is unknown and the assays are timeconsuming.

\section{RFLPs}

The moderately repetitive RFLP probe RG57 (Goodwin et al., 1992b) yields a genetic fingerprint of 25-29 bands (Forbes et al., 1998) and has proved a valuable tool in monitoring $P$. infestans genetic diversity. Many thousands of isolates worldwide have been fingerprinted and an international database of the results constructed (Forbes et al., 1998). The dataset has been important in defining and monitoring (Goodwin and Drenth, 1997) lineages of $P$. infestans and tracking inoculum sources (Zwankhuizen et al., 2000). The method does have disadvantages, however; large amounts of pure DNA are required, it is timeconsuming, the banding patterns can be difficult to interpret and the resultant data are dominant. Furthermore, very little is known about the individual loci that make up the fingerprint, so assessing the likelihood of homoplasy is difficult.

\section{mtDNA haplotype analysis}

The $P$. infestans mitochondrial genome has been sequenced (Paquin et al., 1997) and its RFLP diversity studied in some detail (Carter et al., 1990; Goodwin, 1991; Gavino and Fry, 2002). Uniparentally inherited (Whittaker et al., 1994) mitochondrial DNA markers enable the tracking of specific lineages, providing a useful comparison to markers in the nuclear genome. Although it is a powerful tool for the phylogeographic analysis of many organisms, $P$. infestans mtDNA diversity is relatively limited, with the vast majority of tested isolates falling into two [ $\mathrm{Ia}(\mathrm{A})$ and $\mathrm{IIa}(\mathrm{B})]$ of the six defined haplotypes (Griffith and Shaw, 1998; Gavino and Fry, 2002). Marked regional variation in mtDNA haplotype frequency (Forbes et al., 1998; Griffith and Shaw, 1998) and associations between haplotype and nuclear DNA fingerprint have been observed (Purvis et al., 2001), but neither the cause nor the functional significance (if any) is known. There is no known mechanism of selection acting on the mtDNA (Gavino and Fry, 2002), but the emergence of mtDNA-based resistance to QoI fungicides in other oomycetes (Gisi et al., 2002) indicates a potential selection pressure to consider in future monitoring. The principal method for characterizing $P$. infestans mtDNA type is a PCR-RFLP method (Griffith and Shaw, 1998), but recent sequencing of the IGS has identified additional SNP variation (Wattier et al., 2003) within these groups. Further screening and the design of new protocols suited to highthroughput methods are therefore required.

\section{AFLPs}

Amplified fragment length polymorphisms (Vos et al., 1995) have proved very powerful markers, since they yield many loci per primer combination (Milbourne et al., 1997). They have been central to the genetic mapping of $P$. 
infestans (van der Lee et al., 1997) and resolve at a level appropriate for examining intrapopulation diversity (Knapova and Gisi, 2002; Cooke et al., 2003; Flier et al., 2003). Fingerprinting by AFLPs discriminated almost every isolate (Flier et al., 2003) or every second $P$. infestans isolate (Knapova and Gisi, 2002; Cooke et al., 2003) in studies in Mexico and Europe, respectively. The data are dominant, however, which increases the number of markers required to estimate population parameters (Jorde et al., 1999)Since the method traditionally relies on acrylamide gel electrophoresis and radioactive labelling, the gel-to-gel normalization of the resultant fingerprints represents a challenge, even within a single laboratory. The method is also sensitive to changes in DNA quality and comparisons between laboratories may only be possible when common protocols are adopted and a combination of fluorescent labelling and capillary electrophoresis yields accurately sized digital output under standardized running conditions. The method is also time-consuming and requires very pure $P$. infestans DNA, which means it cannot be applied to infected plant material. In addition, conversion of AFLP bands to locus-specific markers is not straightforward. Comparisons of AFLPs and the methods described below are needed to assess the relative merits of each. Their suitability for examining fine-scale diversity in local populations and highthroughput population genomics (Luikart et al., 2003) is likely to result in their continued use in specific applications.

\section{SSRs}

Simple sequence repeat markers, or microsatellites, have many of the attributes detailed in. With their high variability and dense distribution throughout the genome they have revolutionized the fields of molecular ecology and phylogeography (e.g. Goldstein and Pollock, 1997; Goldstein et al., 1999) as well as proving to be powerful tools for genetic analysis (e.g. Kohn et al., 2000). However, they have not, to date, been exploited widely by plant pathologists, with only a few recent examples of their use in $P$. infestans (Knapova et al., 2001; Knapova and Gisi, 2002), Plasmopara (Gobbin et al., 2003) and Magnaporthe (Kaye et al., 2003). Microsatellites are short fragments of DNA in which motifs of 1-6 bases occur in tandem repeats. Slippage during DNA replication (Goldstein and Pollock, 1997; Li et al., 2002) results in periodic alteration of the repeat length, which is scored by accurate sizing of the PCR-amplified repeat and its immediate flanking sequence. They offer a taxonomic resolution suitable for the analysis of individual isolates within a population and phylogenetic relationships between closely related taxa. Unlike multilocus marker systems such as AFLPs, SSR analysis tends to focus on relatively few markers, but the precise nature of each locus and its length variation are unambiguously defined. This objective 'locus-specific' approach facilitates interisolate and interlaboratory comparisons, which are of great benefit in the analysis of global populations of important taxa such as $P$. infestans. Both alleles at a locus are amplified and discriminated simultaneously, yielding codominant data appropriate for detailed population genetic analysis. Genetic distance, calculated on the basis of allele sharing and size divergence (Goldstein and Pollock, 1997), is also suited to intraspecific and interspecific phylogenetic analysis. Individual loci can be positioned onto a physical map by PCR against multidimensional pools of bacterial artificial chromosome (BAC) clones (Whisson et al., 2001) or onto a genetic map by scoring the alleles in existing mapping populations (van der Lee et al., 1997). The assay is PCR-based and only tiny amounts of relatively 'crude' DNA are required. Thus, DNA extracted from spores washed from a lesion or even a section 
of the infected leaf itself (Gobbin et al., 2003) is adequate, obviating the need for pathogen isolation. A disadvantage of SSRs is the relatively long lead-in time. Fortunately, the lengthy process of enriching a small insert DNA library and sequencing to yield candidate markers for further optimization (Knapova et al., 2001) can now be avoided thanks to the increasing availability of pathogen sequence data. A large amount of such $P$. infestans expressed sequence tag (EST) and noncoding sequence data is now available through public [Phytophthora genome consortium (Waugh et al., 2000)] and private [Syngenta Phytophthora consortium (Lam, 2001)] consortia. At SCRI, P. infestans sequences were screened for the presence of SSR motifs. Subsequent testing of the candidate PCR primer sets against a panel of $P$. infestans isolates showed that approximately $10 \%$ of the putative SSRs were suitable markers (A. K. Lees, SCRI, Dundee, personal communication). Once the discovery and optimization phase is complete, throughput may be increased by amplifying more than one locus per PCR, termed multiplexing. Such approaches are well developed in human forensic testing (Wallin et al., 2002) and may be further refined by the generation of genome-wide frameworks of multiplexed markers (e.g. Tang et al., 2003). Such a system would be a tremendous resource for $P$. infestans research. The first reports on the use of SSRs in the study of $P$. infestans (Knapova et al., 2001; Knapova and Gisi, 2002) demonstrate both the difficulties and the great potential of these markers. Of six SSR loci screened, only three were polymorphic amongst European populations (Knapova and Gisi, 2002). Two of these three loci were tested against 176 isolates from Switzerland and France and revealed four and six allele sizes, respectively, in 21 different combinations, indicating that they have a resolution appropriate for population analysis. No strong associations between SSR genotype, AFLP pattern, mating type or metalaxyl resistance were revealed, suggesting independent segregation of these traits via sexual recombination. Null alleles were recorded with one SSR locus (Knapova and Gisi,2002) and some of the loci recently developed at SCRI (A. K. Lees, SCRI, personal communication) show limited allele diversity. This demonstrates the need for detailed studies to optimize and, if needed, extend the marker set to ensure an appropriate range of SSR loci are available for different research objectives.

\section{SNPs}

Single base-pair differences in DNA, which occur as a result of point mutations (substitutions or insertions/ deletions), are termed single nucleotide polymorphisms. They represent the main source of genetic variation in the genome, comprising, for example, approximately $90 \%$ of the variation in the human genome (Collins et al., 1998). SNP-based markers share many of the advantages of SSRs) and they are thus powerful tools for genetic analysis, as well as for the estimation of population parameters such as genetic distances, divergence times and gene flow (reviewed in Brumfield et al., 2003). Their potential is being investigated because the estimation of such parameters from sequences of single loci (gene trees) is less powerful than from a suite of unlinked markers representing a genome-wide picture of population history (Brumfield et al., 2003). Because of the difficulty of estimating mutation rates at hypervariable SSR loci, it is argued that SNPs are a more powerful tool. However, approximately three times more SNPs than SSRs are required and the concepts and tools for interpreting SNP diversity on the basis of coalescent theory are still under development (Brumfield et al., 2003). SNP discovery is a lengthy process and assay development more technologically 
challenging than for SSRs. These factors suggest SSRs will remain the marker of choice for $P$. infestans population analysis for the immediate future. SNP markers do, however, have specific advantages for particular applications. Unlike SSRs they are not constrained to tandem repeat regions and assays may be based on the specific SNP responsible for an amino-acid replacement in a functional protein. They will thus be vital in the direct monitoring of the frequencies of functional alleles (e.g. virulence loci) in natural and experimental populations. In combination with neutral markers, such data will be critical in the estimation of selection pressures on a range of key functional traits. Technical advances in SNP discovery and scoring and increasing $P$. infestans genome sequence data are likely to increase the use of SNPs. A small number of SNPs have already been identified and much-needed comparisons of population parameters on the basis of SNPs, SSRs and AFLP markers are underway (D. Cooke and S. Hussain, SCRI, personal communication).

\section{Sequence analysis}

Recognized as a powerful method for reconstructing phylogenetic relationships between species (Cooke et al., 2000), sequence analysis is increasingly being applied to the reconstruction of gene genealogies or phylogeography within fungal species (Koufopanou et al., 1997; Carbone and Kohn, 2001a; Banke et al., 2004). Improved sequencing chemistry and reduced costs, combined with new concepts (Carbone and Kohn, 2001b; Templeton, 2004) and analysis tools (Clement et al., 2000; Stephens et al., 2001), are making the sequencing of several alleles from many individual isolates from a population a viable option. It is increasingly recognized that traditional phylogenetic methods are based on assumptions that do not apply at a population level (Clement et al., 2000), and more sophisticated methods, in which haplotype data are analysed by coalescent-based methods to create a population genetic framework, are being developed (e.g. Posada et al., 2000; Templeton, 2004). From this framework, the probability of obtaining a given genealogical structure under different population genetic models is calculated. A haplotype is a set of polymorphisms in a defined length of DNA sequence that can be assigned unambiguously to one chromosome (Brumfield et al., 2003) and is the raw data for much phylogeographic analysis. A complication with diploid organisms such as $P$. infestans is that, for each allele, the two haplotypes must first be 'extracted' from the pooled PCR-derived diplotype sequence data. To obviate the need to derive haplotypes by expensive cloning and sequencing, accurate theoretical approaches have been developed (Clark, 1990; Stephens et al., 2001). Sequencing, and subsequent haplotype analysis, is perhaps most appropriate for investigating the broader issues of $P$. infestans diversity, e.g. in phylogeographic analyses to confirm the centre of diversity and patterns of longrange migration or to examine the interface between populations and species to unravel the origins of $P$. infestans and its sister taxa on wild Solanum species (Gomez et al., 2003). As well as their use as neutral markers in population analysis, sequence data are valuable in estimating the type and extent of selection pressure on functional genes. The sequencing of a putative virulence gene from many isolates and analysis of the ratio of the mutations in the DNA sequence that result in a change (replacement or nonsynonomous) or no change (synonomous or silent) to the resultant amino acid yields the $\mathrm{Ka} / \mathrm{Ks}$ ratio (Hurst, 2002). From this ratio, inferences can be made about whether the gene is under stabilizing or diversifying selection, and, from this, predictions on the functional role of the gene can be made (Bos et al., 2003). 


\section{Main areas of molecular epidemiology}

A. Pathogen Identification and diagnosis

B. Quantification of Initial inoculums and infection

C.Pathogen temporal development

D. Pathogen spatial distribution.

E. Pathogen long distance dispersal and migration

F. Dynamics of pathogen population structures

G. Interactions between host resistance and pathogen virulence and pathogenicity

\section{A. Pathogen Identification and diagnosis}

It is required for the pathogens because it is difficult to distinguish from other species from morphologically and also for the pathogens to be Identified from soil, seed, plant tissue, water, and other bio or abio environments

Basic steps are-

- Design and create the species-specific primer(s),

- Test the primer's specificity using a broad range of species,

- Test the sensitivity of the primer(s).

The design of species-specific primers is based on:

Species-specific sequences of internal transcribed spacer (ITS)

Species-specific sequences of randomly amplified polymorphic DNA region (RAPD) and Species-specific repetitive sequences.

\section{B. Quantification of initial inoculum and infection}

Initial inoculum:

- Propagule density in soil, water or plant debris,

- Spore density in the air,

- Latent infections in plant tissues,

- Infected seeds of seed-borne diseases,

- Disease intensity in the original source of the long-distance dispersal pathogens.

Molecular techniques can be used to quantify the initial inoculum of some diseases which is not at all possible in traditional epidemiological methods.

\section{Pathogen temporal development}

This studies focus on pathogen population dynamics over time and the isolates should be collected from different time in same or different fields.

Also proper molecular makers should be used to produce polymorphic DNA haplotypes or genotypes.

The analysis will include:

1. Genetic distances among sampling populations at different times.

2. Determination of genetic identity and distance among sampling populations.

3. Determination of changes in genetic structure among populations. 
Percentage of polymorphonic loci and genetic diversity for each sampling group

\begin{tabular}{|c|c|c|c|c|}
\hline orchard & Sampling group & $\begin{array}{l}\text { Percentage of } \\
\text { polymorphic } \\
\text { loci }\end{array}$ & $\begin{array}{l}\text { Genetic } \\
\text { diversity }\end{array}$ & $\begin{array}{l}\text { Shannon's } \\
\text { info index }\end{array}$ \\
\hline potato & $\mathrm{Gt}$ & 78.05 & $0.25(0.20)$ & $0.37(0.28)$ \\
\hline & $\mathrm{Gf}$ & 75.61 & $0.25(0.20)$ & $0.38(0.29)$ \\
\hline & $\mathrm{Gff}$ & 63.41 & $0.21(0.19)$ & $0.31(0.28)$ \\
\hline & $\mathrm{Gh}$ & 60.98 & $0.21(0.19)$ & $0.32(0.28)$ \\
\hline & & & & \\
\hline tomato & $\mathrm{AS}$ & 56.1 & $0.17(0.19)$ & $0.26(0.27)$ \\
\hline & $\mathrm{FL}$ & 58.54 & $0.20(0.21)$ & $0.31(0.29)$ \\
\hline & $\mathrm{FR}$ & & $0.22(0.20)$ & $0.33(0.26)$ \\
\hline
\end{tabular}

\section{Pathogen spatial distribution}

Pathogen isolates should be collected from different geographical locations and proper molecular makers should be used for the spatial distribution and these markers should show the polymorphism among isolates. Also a PCR with the special primers or probes should be performed, and the polymorphic DNA patterns or a specific DNA fingerprint can be used in data analysis.

The data analyses may include:

1. geographical populations,

2. Clustering analysis to determine the existence of isolation or gene flow among geographic populations.

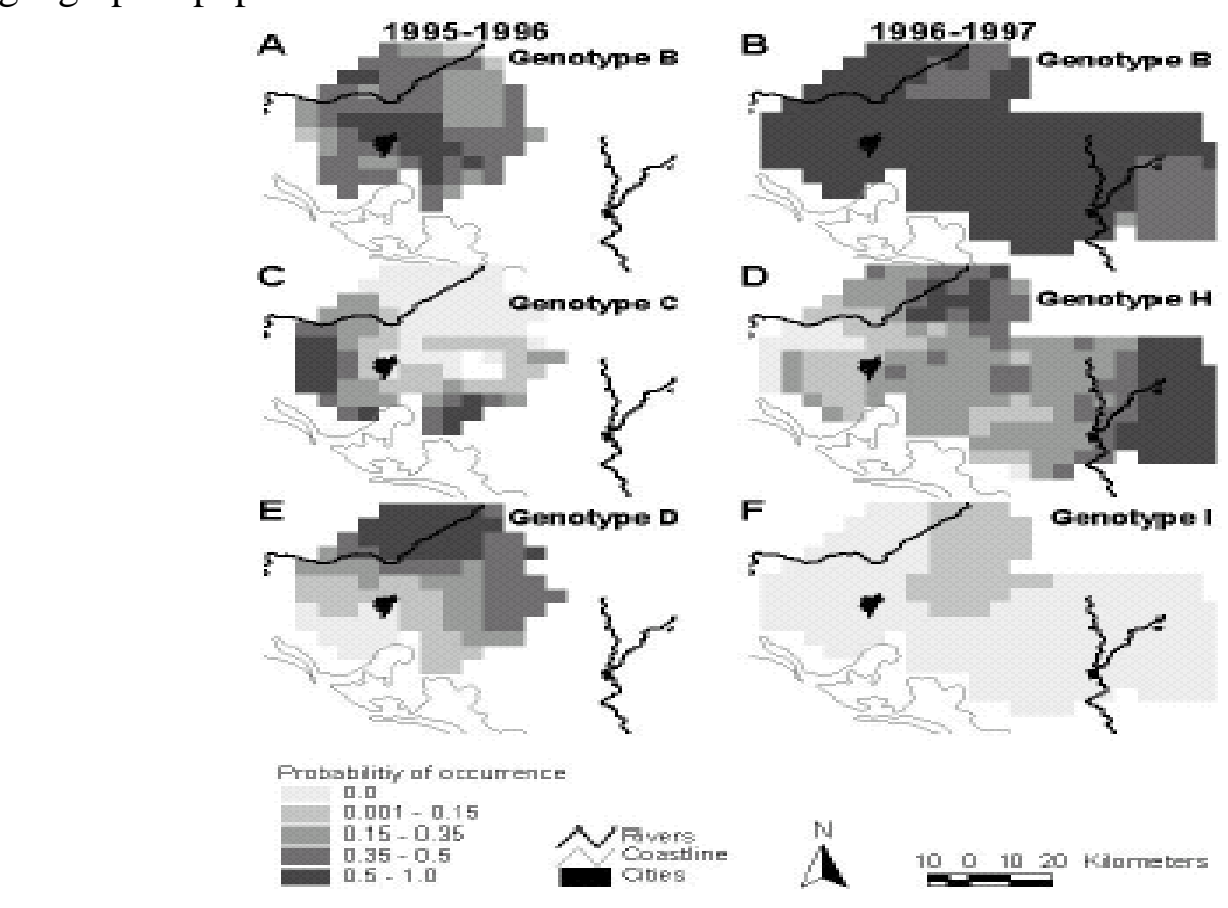

3. Using UPGMA and genetic identity to determine the relationship between genetic distance and geographic distances among populations.

GIS is an useful tool to quantify the above relationships

\section{Each isolate was characterized by}

1) According to their mating types, allozyme at the glucose-6-phosphate isomerase (Gpi) and peptidase (Pep) loci,

2) restriction fragment length polymorphizm (RFLP) with probe RG57 (different races), metalaxyl sensitivity and aggressiveness 
- There are two small areas where the three genotypes had a similar probability of occurrence.

- Six different RFLP genotypes were represented.

- In 1996-1997, three RFLP banding pattern genotypes were found. Genotype "B" had the highest probability of occurrence in most areas

- The genotype "I" had a low probability of occurrence, with the probability above 0.1 only in a small area.

\section{E. Pathogen long-distance dispersal and migration}

Here the studies focus on origin or longdistance dispersal of the plant pathogens. The pathogen isolates should be collected from different ecological or geographical regions or even different continents. Also different PCR processes could be used by using some specific molecular makers including speciesspecific makers, race-specific makers, and so forth. Analysis of Population Structures and Dynamics of Phytopthora infestans in Mexico by Using Microsatellite Primed-PCR. Here the isolates were collected from potato and tomato orchards in 2001.

The actual time of collection in the plum orchard, apothecia, fruit is at mid-season and fruit at harvest. And the time of collection in the prune orchard: mummies in early spring, blossoms, fruit at mid-season, and fruit before harvest.

\section{F. Dynamics of pathogen population structures}

The information on pathogen population structure is important to understand pathogen evolution, population diversity and related disease development. And the special molecular makers are needed to determine the variation of genetic structures of different populations and their changes over time and space. Specific analyses are needed to determine how disease development is related to changes in pathogen population structures. This information is useful to determine disease management strategies.

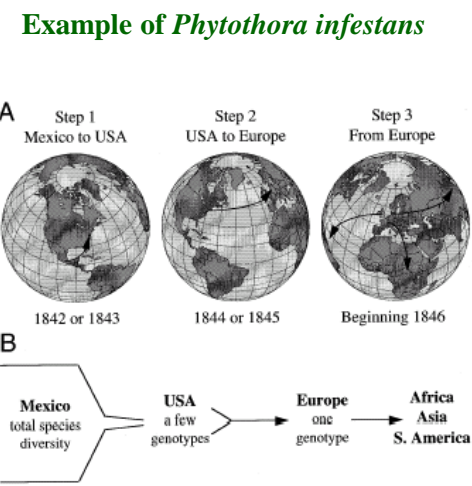

From Goodwin, (Phytopathology 87:462-473).

\section{G. Interactions between host resistance and pathogen virulence}

This studies emphasize on determination of pathogen pathogenicity or virulence by using fast and accurate molecular methods. The important areas may include:

1. Fast identification of pathogen races,

2. Determination of geographic distribution of races and different pathogenicities, 
3. Evaluation of pathogen evolution over time and space.

4. Providing information on resistance deployment and decision support for resistance applications.

5. Prediction of disease development and dynamics of pathogen races.

Various diseases caused by P.infestans

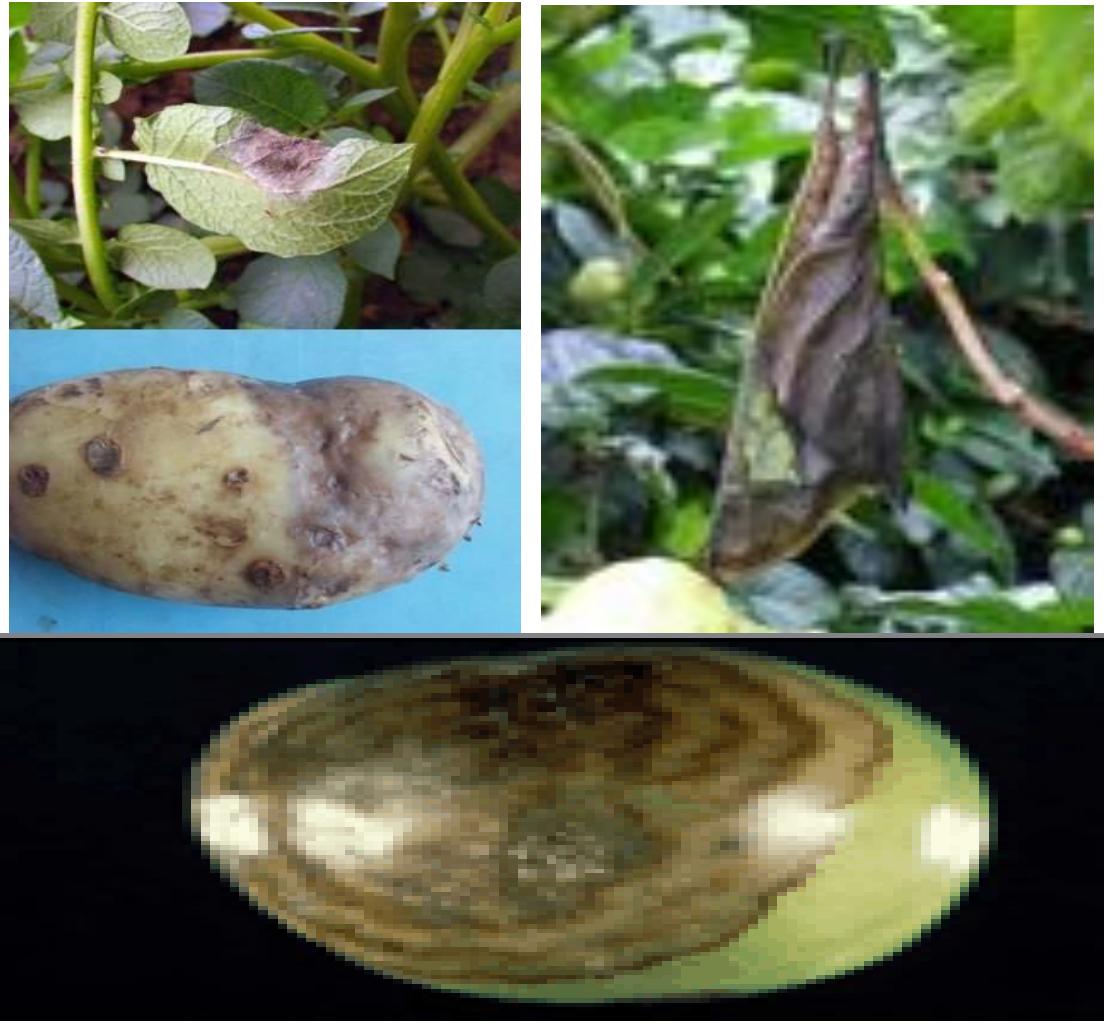

Disease cycle of the fungus P.infestans
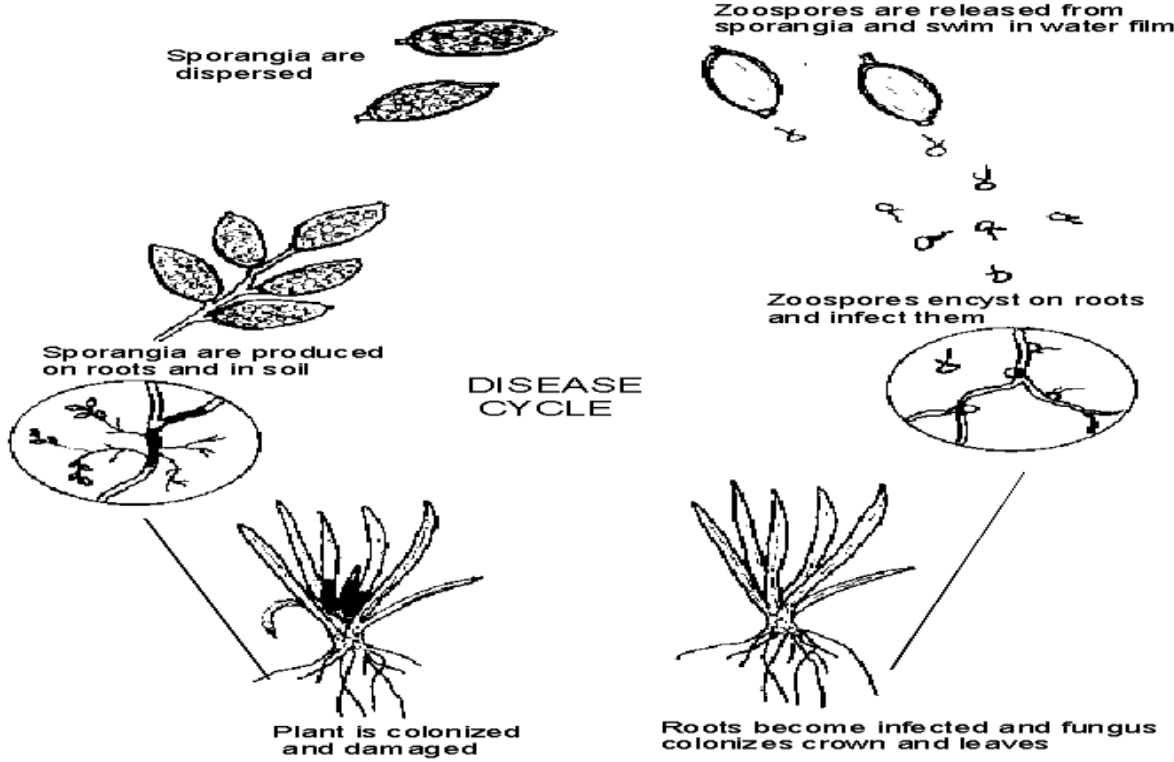

Roots become infected and 
Fig.1 The fungus is dispersed by wind-borne sporangia, which are produced on branched hyphae (sporangiophores) that emerge from the stomata of infected leaves in humid conditions

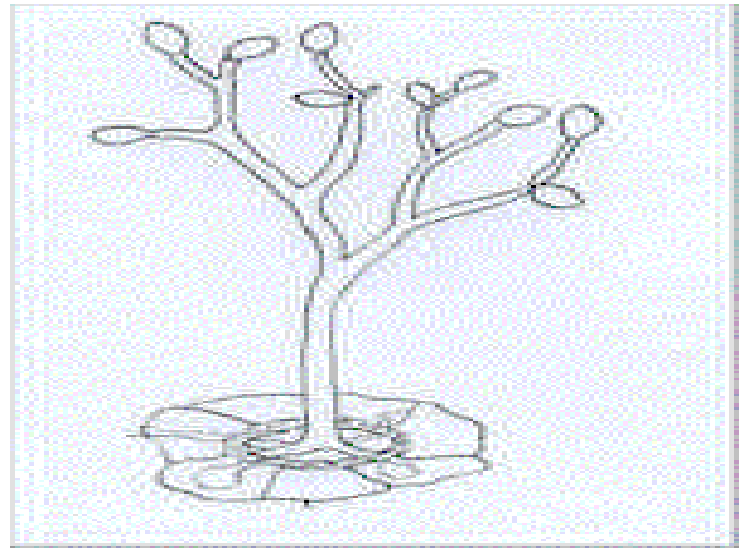

Fig.2 sporangia germinate either by releasing zoospores or by producing a hyphal outgrowth

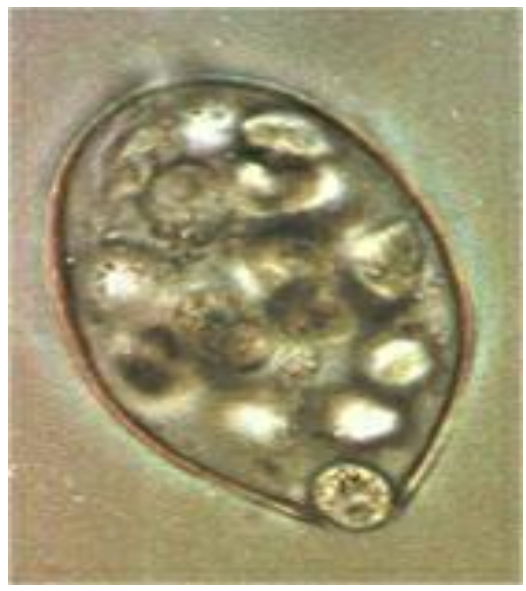

Life cycle of the fungus P.infestans

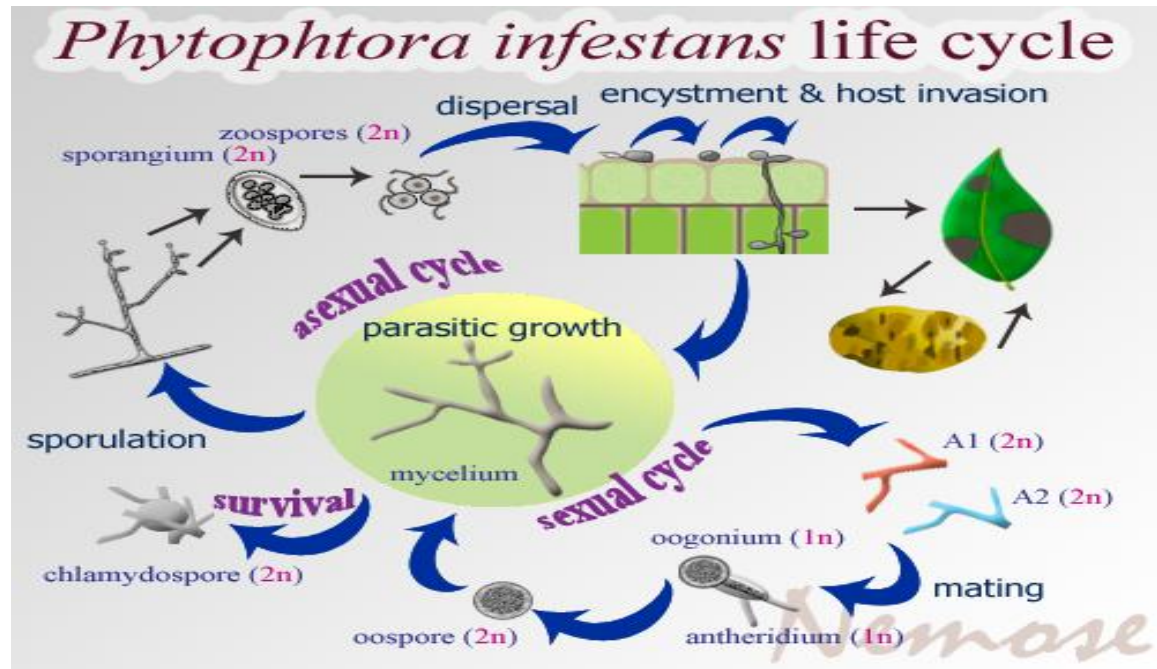




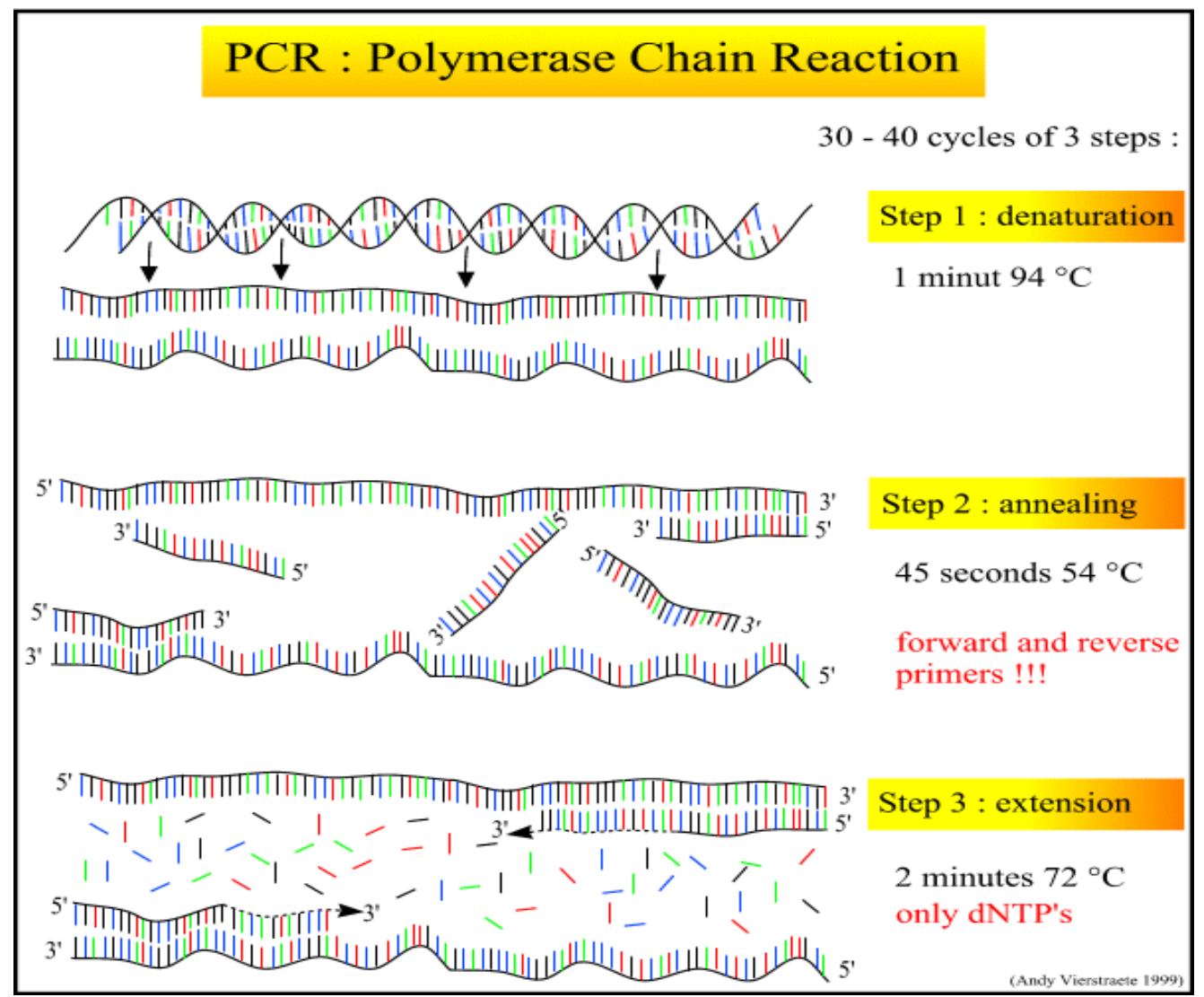

AFLP procedure

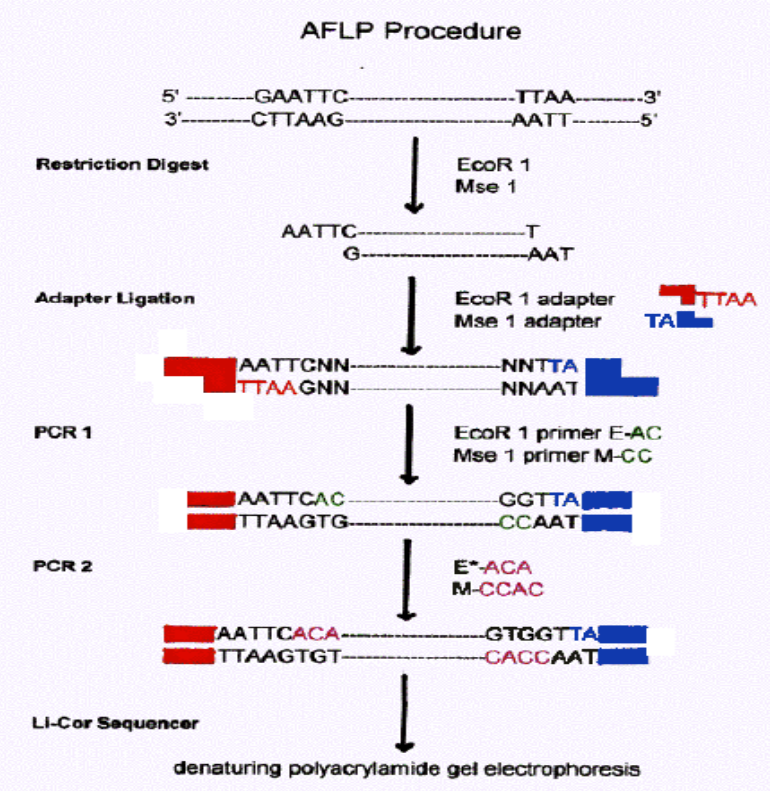



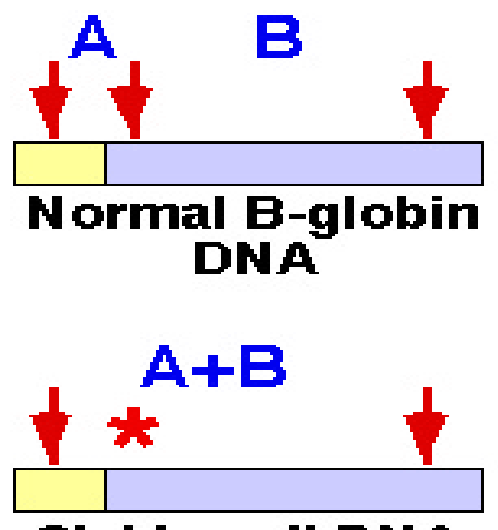

Sickle-cell DNA

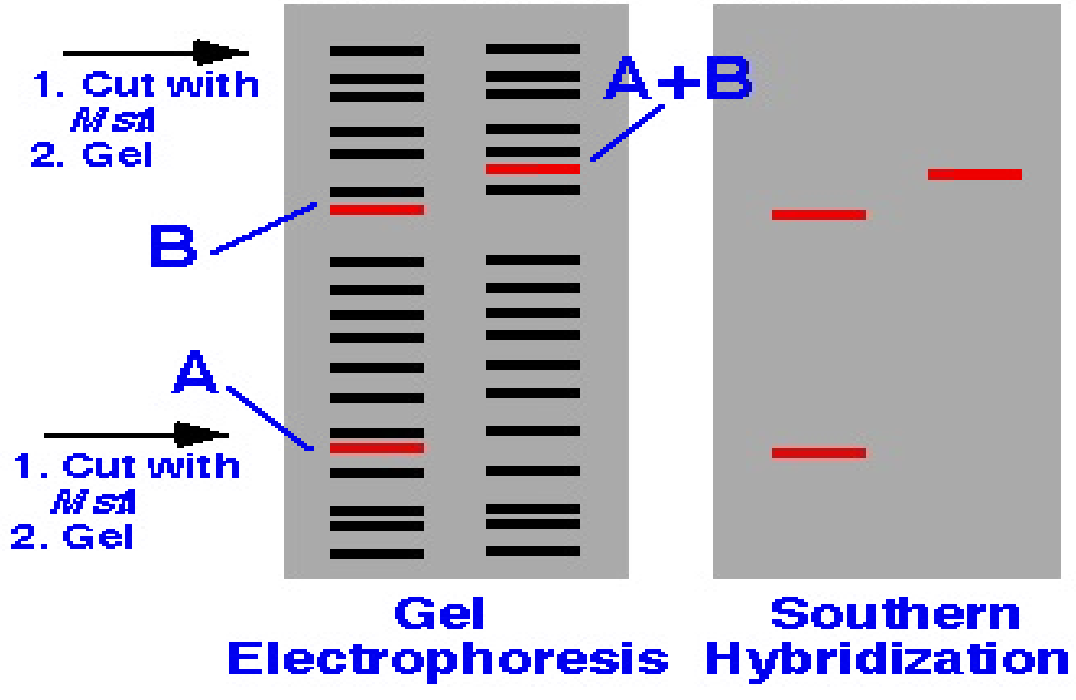

Steps of Real Time PCR

1

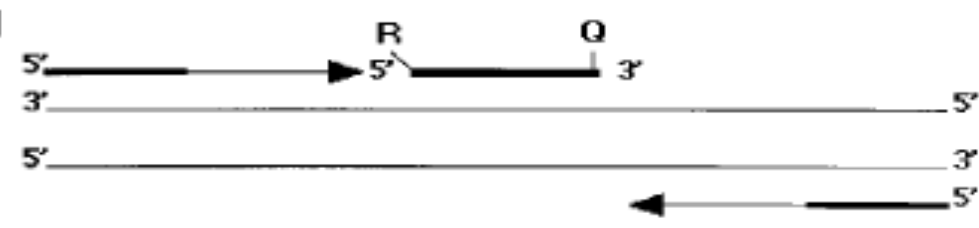

2
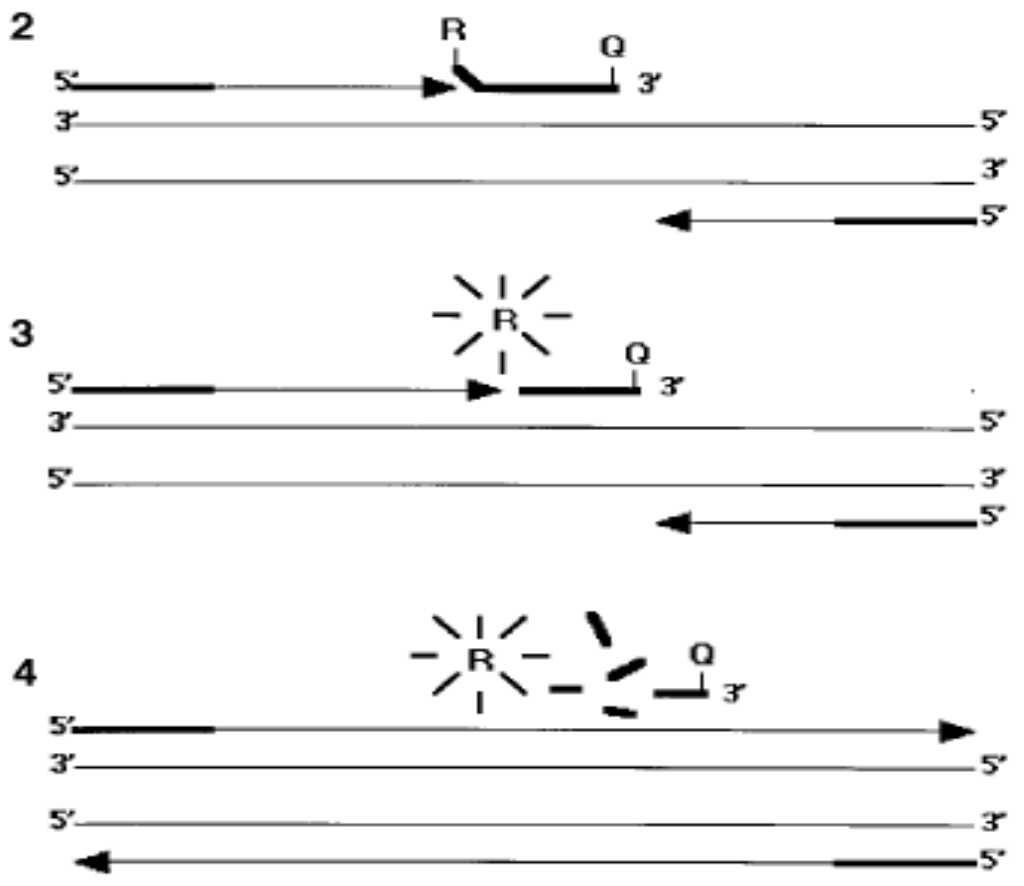

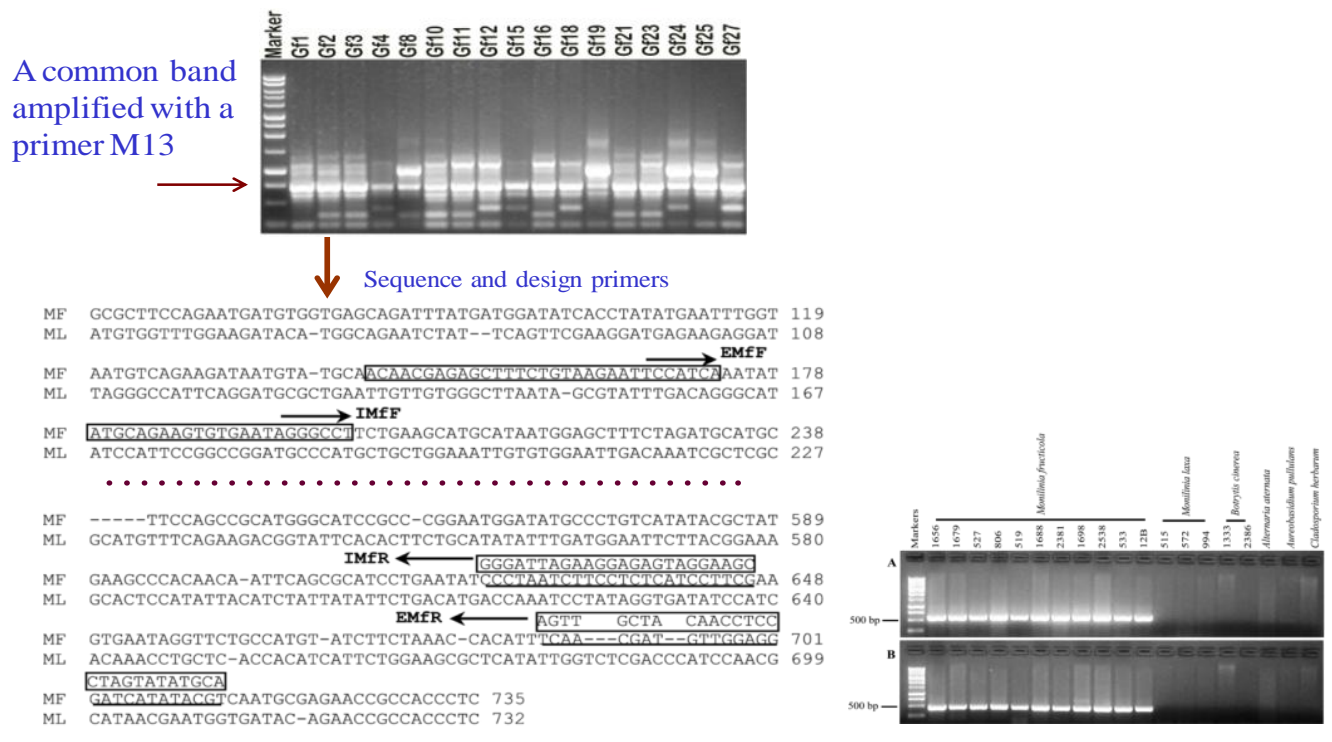

\section{A list of selected pathogens, markers, and authors for pathogen diagnosis}

\begin{tabular}{|c|c|c|}
\hline & & \\
\hline $\begin{array}{l}\text { Iternaria alternata } \\
\text { lasmodiophora brassicae } \\
\text { hizoctonia solani AG4 or } 8 \\
\text { rwinia carotovora subsp. Atroseptica } \\
\text { lavibacter michiganensis subsp. michiganensis } \\
\text { tagonospora nodorum and Septoria tritici } \\
\text { eminivirus subgroup III } \\
\text { hytophthora cinnamomi } \\
\text { ythium spp } \\
\text { usarium culmorum, F.graminearum, F. avenaceut } \\
\text { lagnaporthe poae } \\
\text { anthomonas axonopodis pv. citri } \\
\text { eloidogyne arenaria } \\
\text { ythium ultimum } \\
\text { anthomonas campestris pv. phaseoli } \\
\text { ylella fastidiosa } \\
\text { erticillium tricorpus }\end{array}$ & $\begin{array}{l}\text { orimers } \\
\text { ction } \\
\text { robe } \\
\text { om plasid-borne genes } \\
\text { ecific primers } \\
\text { gene sequences } \\
\text { robe } \\
\text { NA gene specers } \\
\text { le primers from RAPD }\end{array}$ & $\begin{array}{l}\text { Johnson, et al. } \\
\text { Faggian, et al. } \\
\text { Brisbane, et al. } \\
\text { De Boer, et al. } \\
\text { Dreier, et al. } \\
\text { Beck and Ligon } \\
\text { Wyatt and Brown } \\
\text { Judelson, et al. } \\
\text { Klassen, et al. } \\
\text { Schilling, et al. } \\
\text { Buting, et al. } \\
\text { Hartung, et al. } \\
\text { Baum, et al. } \\
\text { Levesque, et al. } \\
\text { Audy et al. } \\
\text { Minsavage et al. } \\
\text { Moukhamedov }\end{array}$ \\
\hline
\end{tabular}


microsatellite primers used in PCR

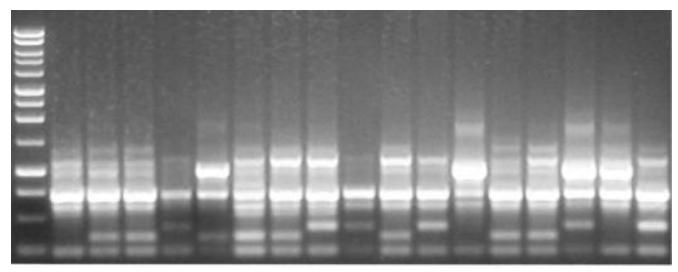

-Five microsatellite primers, M13, (AAG) ${ }_{8}$, $(\mathrm{AG})_{8} \mathrm{C},(\mathrm{GACA})_{4}$, and $(\mathrm{AG}) 8 \mathrm{C}$, were used in the PCR amplification.

Data analyses included:

-UPGMA tree development. -Calculation of genetic diversity for each sampling group. -Calculation of genetic identity and distance among sampling groups.

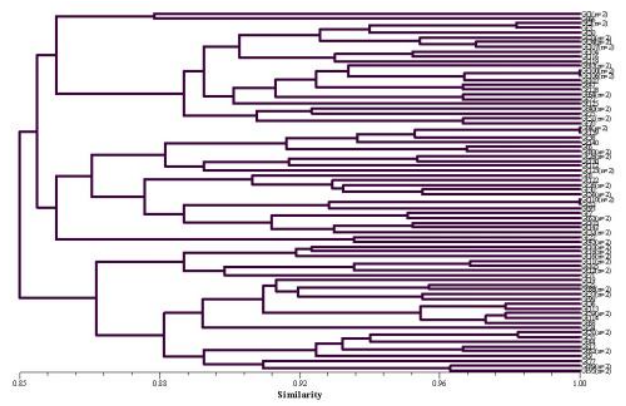

Ideal system for pathogenicity in molecular epidemiology

\section{The ideal system}

\begin{tabular}{|c|c|c|c|c|c|c|c|}
\hline \multirow{3}{*}{$\begin{array}{l}\text { Pathogenicity } \\
\text { pattern }\end{array}$} & \multirow[b]{2}{*}{ Isolate } & \multicolumn{5}{|c|}{ Variety } & \multirow[b]{2}{*}{ Race } \\
\hline & & A & B & C & D & $E$ & \\
\hline & $a$ & - & + & + & - & + & 1 \\
\hline & b & + & + & - & + & - & 2 \\
\hline & C & - & - & + & - & + & 3 \\
\hline & d & + & + & - & - & - & 4 \\
\hline & e & - & + & - & + & - & 5 \\
\hline
\end{tabular}

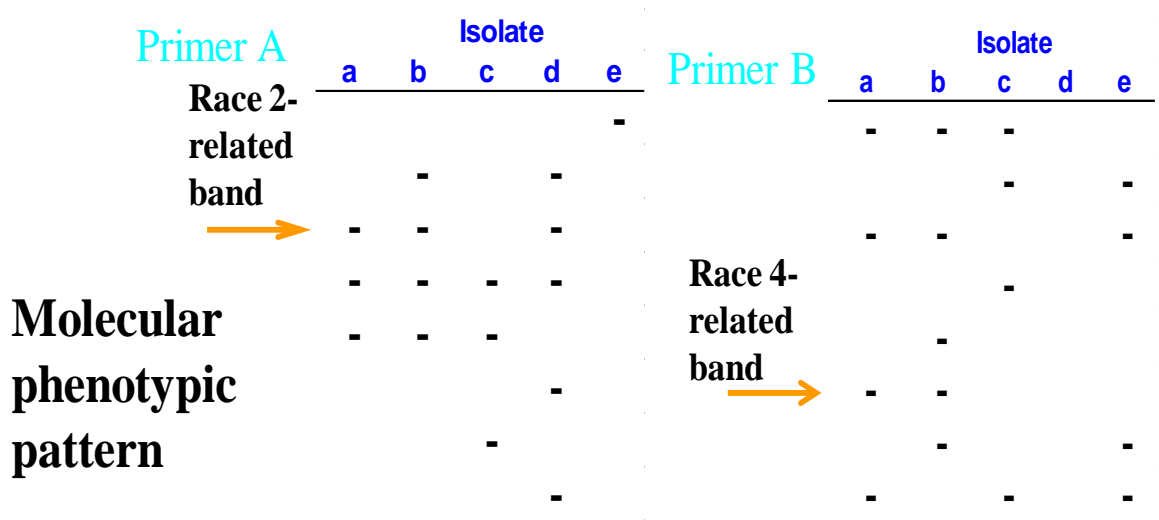




\section{Conclusions and future prospect}

Since the recognition of $P$. infestans as a plant pathogen and also as the cause of famine and population displacement in Ireland in the mid 1800s, the biology, genetics and pathogenic strategies have been studied. However, relatively little research has explored Phytophthora diseases at the molecular level. The wealth of data comprising sequences involved in different developmental stages as well as infection stages should help in establishing expression profiles to understand mechanisms underlying different phenomena. There is a need however, to develop systematic gene disruption techniques to help elucidate the functional role of these genes. Evidently sequencing the genome of $P$. infestans will prove a valuable resource. Annotation of the genome of $P$. infestans will be facilitated by large unigene set generated from the ESTs as well as available physical and genetic maps. A complete genome sequence can be used for comparative analysis amongst Phytophthora species or with other organisms to decipher, for example the basic set of genes that makes $P$. infestans a plant pathogen. There is much hope that in the near future these resources will help us understand mechanisms underlying pathogenicity and host responses and ultimately lead to the development of improved strategies to control $P$. infestans. Undoubtedly, answers to some long-standing and important questions in fundamental and applied $P$. infestans research will emerge as the potential of modern genetic markers is realized, and as they are developed and exploited by the international research community. Fundamental to this is the release of $P$. infestans DNA sequence data. Of the methods discussed, SSRs appear to offer the greatest potential across a wide range of applications and should be developed further. Functional genomics is also characterizing the role of many novel $P$. infestans genes and the parallel tracking of neutral and functional markers will help to identify the forces driving pathogen evolution. Whichever marker systems are advanced, their potential will be maximized by the rapid public release of protocols and applications, ideally collated into a database alongside information on their map locations. The establishment of a European database comprising detailed information on $P$. infestans populations and their genetic characterization has already begun under the EUCABLIGHT project (www.eucablight.org). A comparison of the resolution and suitability of existing and newer DNA-based markers is also being undertaken on standard isolate collections to relate the 'old' and 'new' datasets. Cooperative approaches will be important in achieving the critical mass of detailed information necessary to reveal the driving forces and practical implications of population changes on this scale. Closer collaborations between specialists in the fields of plant pathology, epidemiology, population genetics/molecular ecology, $P$. infestans molecular biology and plant breeding are advocated to enable such progress. With increasing environmental and economic pressure to reduce agrochemical inputs, future sustainable management strategies ought to place more emphasis on host resistance (natural or 'engineered'). Their success will, however, hinge on understanding current diversity and predicting future responses of $P$. infestans populations to such resistance deployment. A population genetics approach that reveals the genetic structure of populations at both international and field scales and determines the extent of gene flow between populations and the balance between the forces of natural selection and chance effects of genetic drift and migration is essential to this understanding. As more markers are developed and the genome saturated, the approach will move towards the simultaneous analysis of many markers across 
subsets, or even the whole genome, and a subsequent examination of linkage disequilibrium (LD), which has the power to separate locus-specific effects from those affecting the whole genome (Luikart et al., 2003). Many questions remain: for example, the frequency of each mating type is important, but the cause of the marked spatiotemporal variation in mating-type ratios is unknown. Also, why, in some regions have both mating types coexisted for many years with little evidence of mating? Perhaps it relates to the compatibilities of the specific A1 and A2 mating-type strains within a region? What are the processes of hostpathogen coevolution in natural populations in South and Central America, and how do they differ from those in the 'artificial' $S$. tuberosum- and Lycopersicon esculentumdominated agroecosystems? From a European perspective, are populations dominated by isolates introduced in the mid-1970s or have there been subsequent influxes? Is there any substructuring of European populations, or has long-range spread by wind and seed tubers created a random mosaic? To what extent and at what rate do local populations (if they exist) adapt to the environmental conditions, cultivars and management strategy in that region? How many samples are needed for an accurate reflection of the population structure? Also, in terms of breeding strategies, what is the selection pressure on different pathogen $A v r$ genes and will some plant $\mathrm{R}$ genes be more useful than others for engineered resistance?

\section{References}

Abu-El Samen FM, Secor GA, Gudmestad NC, 2003. Variability in virulence among asexual progenies of Phytophthora infestans. Phytopathology 93, 293-304.

Avrova AO, Venter E, Birch PRJ, Whisson SC, 2003. Profiling and quantifying differential gene transcription in Phytophthora infestans prior to and during the early stages of potato infection. Fungal Genetics and Biology 40, 4-14.
Banke S, Peschon A, McDonald BA, 2004. Phylogenetic analysis of globally distributed Mycosphaerella graminicola populations based on three DNA sequence loci. Fungal Genetics and Biology 41, 226-38.

Barton NH, Charlesworth B, 1998. Why sex and recombination? Science 281, 1986-9.

Birch PRJ, Avrova AO, Armstrong M, Venter E, Taleb N, Gilroy EM, Phillips MS, Whisson SC, 2003. The potato - Phytophthora infestans interaction transcriptome. Canadian Journal of Plant Pathology 25, 226-31.

Birch PRJ, Kamoun S, 2000. Studying interaction transcriptomes: coordinated analyses of gene expression during plant-microbe interactions. New Technologies for Life Sciences: a Trends Guide. (Supplement to Elsevier Trends Journals, December, 2000), 77-82.

Birch PRJ, Whisson SC, 2001. Phytophthora infestans enters the genomics era. Molecular Plant Pathology 2, 257-63.

Bos JI, Torto TA, Ochwo M, Armstrong M, Whisson SC, Birch PRJ, Kamoun S, 2003. Intraspecific comparative genomics to identify avirulence genes from Phytophthora. New Phytologist 159, 63-73.

Bradshaw NJ, Vaughan TB, 1996. The effect of phenylamide fungicides on the control of potato late blight (Phytophthora infestans) in England and Wales from 1978 to 1992. Plant Pathology 45, 249-69.

Brasier CM, 1992. Evolutionary biology of Phytophthora. I. Genetic system, sexuality and the generation of variation. Annual Review of Phytopathology 30, 153-71.

Brumfield RT, Beerli P, Nickerson DA, Edwards SV, 2003. The utility of single nucleotide polymorphisms in inferences of population history. Trends in Ecology and Evolution 18, 249-56.

Brurberg MB, Hannukkala A, Hermansen A, 1999. Genetic variability of the potato late blight pathogen Phytophthora infestans in Norway and Finland. Mycological Research 103, 1609-15.

Burdon JJ, Silk J, 1997. Sources and patterns of diversity in plant pathogenic fungi. Phytopathology 87, 664-9.

Carbone I, Kohn LM, 2001a. A microbial populationspecies interface: nested cladistic and coalescent interference with multilocus data. Molecular Ecology 10, 947-64.

Carbone I, Kohn LM, 2001b. Multilocus nested haplotype networks extended with DNA fingerprints show common origin and fine-scale, ongoing genetic divergence in a wild microbial metapopulation. Molecular Ecology 10, 2409-22. 
Carter DA, Archer SA, Buck KW, Shaw DS, Shattock RC, 1990. Restriction fragment polymorphisms of mitochondrial DNA of Phytophthora infestans. Mycological Research 94, 1123-8.

Carter DA, Archer SA, Buck KW, Van der Lee T, Shaw DS, Shattock RC, 1999. The detection of non-hybrid, trisomic and triploid offspring in sexual progeny of a mating of Phytophthora infestans. Fungal Genetics and Biology 26, 198208.

Caten CE, Jinks JL, 1968. Spontaneous variability of single isolates of Phytophthora infestans. I. Cultural variation. Canadian Journal of Botany 46, 329-48.

Chauvet S, van der Velde M, Imbert E, Guillemin ML, Mayol M, Riba M, Smulders MJM, Vosman B, Ericson L, Bijlsma R, Giles BE, 2004. Past and current gene flow in the selfing, wind-dispersed species Mycelis muralis in western Europe. Molecular Ecology 13, 1391-407.

Clark AG, 1990. Inference of haplotypes from PCRamplified samples of diploid populations. Molecular Biology and Evolution 7, 111-22.

Clement M, Posada D, Crandall KA, 2000. TCS: a computer program to estimate gene genealogies. Molecular Ecology 9, 1657-9.

Cohen Y, 2002. Populations of $P$. infestans in Israel underwent three major genetic changes during 1983-2000. Phytopathology 93, 300-7.

Collins FS, Brooks LD, Chakravarti A, 1998. A DNA polymorphism discovery resource for research on human genetic variation. Genome Research 8, 1229-31.

Cooke DEL, Drenth A, Duncan JM, Wagels G, Brasier CM, 2000. A molecular phylogeny of Phytophthora and related Oomycetes. Fungal Genetics and Biology 30, 17-32.

Cooke DEL, Young V, Birch PRJ, Toth R, Gourlay F, Day JP, Carnegie S, Duncan JM, 2003. Phenotypic and genotypic diversity of Phytophthora infestans populations in Scotland (1995-97). Plant Pathology 52, 181-92.

Dangl JL, Jones DG, 2001. Plant pathogens and integrated defence responses to infection. Nature 411, 826-33.

Davidse LC, Lovijen D, Turkensteen LJ, van der Wal D, 1981. Occurrence of metalaxyl resistant strains of Phytophthora infestans in Dutch potato fields. Netherlands Journal of Plant

Pathology 87, 65-8.

Day JP, Shattock RC, 1997. Aggressiveness and other factors relating to displacement of populations of Phytophthora infestans in England and Wales. European Journal of Plant

Pathology 103, 379-91.

Dowley LJ, Griffin D, O’Sullivan E, 2002. Two decades of monitoring Irish populations of Phytophthora infestans for metalaxyl resistance. Potato Research 45, 79-84.

Dowley LJ, O’Sullivan E, 1981. Metalaxyl-resistant strains of Phytophthora infestans (Mont.) de Bary in Ireland. Potato Research 24, 417-21.

Dowley LJ, O’Sullivan E, 1985. Monitoring metalaxyl resistance in populations of Phytophthora infestans. Potato Research 28, 531-4.

Drenth A, Tas ICQ, Govers F, 1994. DNA fingerprinting uncovers a new sexually reproducing population of Phytophthora infestans in the Netherlands. European Journal

of Plant Pathology 100, 97-107.

Fisher MC, Rannala B, Chaturveid Taylor JW, 2002. Disease surveillance in recombining pathogens: multilocus genotypes identify sources of human Coccidioides infections. Proceedings of the National Academy of Science, USA 99, 9067-71.

Flier WG, Grünwald NJ, Kroon LPNM, Sturbaum AK, van den Bosch TBM, Garay-Serrano E, LozoyaSaldaña H, Fry WE, Turkensteen LJ, 2003. The population structure of Phytophthora infestans from the Toluca valley of Central Mexico suggests genetic differentiation between populations from cultivated potato and wild Solanum spp. Phytopathology 93, 382-90.

Forbes GA, Goodwin SB, Drenth A, Oyarzun P, Ordoñez ME, Fry WE, 1998. A global marker database for Phytophthora infestans. Plant Disease 82, 811-8.

Fry WE, Goodwin SB, 1997. Resurgence of the Irish potato famine fungus. Bioscience 47, 363-71.

Fry WE, Goodwin SB, Matuszak JM, Spielman LJ, Milgroom MG, Drenth A, 1992. Population genetics and intercontinental migrations of Phytophthora infestans. Annual Review of Phytopathology 30, 107-29.

Gallegly ME, Galindo J, 1957. The sexual stage of Phytophthora infestans in Mexico. Phytopathology 47, 13 (Abstract).

Gans P, 2003. The rational use of fungicides in combination with cultivar resistance. In: Schepers HTAM, Westerdijk CE, eds. Proceedings of the Seventh Workshop of a European Network for Development of an Integrated Control Strategy of Potato Late Blight, Poznan, Poland, October 2002.

Wageningen, the Netherlands: Applied Plant Research, 59-66. (PPO-Special Report No. 9.)

Gavino PD, Fry WE, 2002. Diversity in and evidence for selection on the mitochondrial genome of Phytophthora infestans. Mycologia 94, 781-93.

Gavino PD, Smart CD, Sandrock RW, Miller JS, Hamm PB, Yun Lee T, Davis RM, Fry WE, 2000. Implications of sexual reproduction for 
Phytophthora infestans in the United States:

generation of an aggressive lineage. Plant Disease 84, $731-5$.

Gisi U, Cohen Y, 1996. Resistance to phenylamide fungicides: a case study with Phytophthora infestans involving mating type and race 549-72. structure. Annual Review of Phytopathology 34,

Gisi U, Sierotzki H, Cook A, McCaffery A, 2002. Mechanisms influencing the evolution of resistance to Qo inhibitor fungicides. Pest Management Science 58, 859-67.

Gobbin D, Pertot I, Gessler C, 2003. Identification of microsatellite markers for Plasmopara viticola and establishment of high throughput method for SSR analysis. European Journal of Plant Pathology 109, 153-64.

Goldstein DB, Pollock DD, 1997. Launching microsatellites: a review of mutation processes and methods of phylogenetic inference. Journal of Heredity 88, 335-42.

Goldstein DB, Roemer GW, Smith DA, Reich DE, Bergman A, Wayne RK, 1999. The use of microsatellite variation to infer population structure and demographic history in a natural model system. Genetics 151, 797-801.

Gomez L, Thorne JL, Ristaino JB, 2003. Molecular evolution of Phytophthora infestans. Phytopathology 93, S30 (Abstract).

Goodwin SB, 1991. DNA polymorphisms in Phytophthora infestans: the Cornell experience. In: Lucas JA, Shattock RC, Shaw DS, Cooke LR, eds. Phytophthora. Cambridge, UK:

Cambridge University Press, 256-71.

Goodwin SB, 1997. The population genetics of Phytophthora. Phytopathology 87, 462-73.

Goodwin SB, Cohen BA, Fry WE, 1994. Panglobal distribution of a single clonal lineage of the Irish potato famine fungus. Proceedings of the National Academy of Science, USA 91,

$11591-5$.

Goodwin SB, Drenth A, 1997. Origin of the A2 mating type of Phytophthora infestans outside Mexico. Phytopathology 87, 992-9.

Goodwin SB, Drenth A, Fry WE, 1992a. Cloning and genetic analysis of two highly polymorphic, moderately repetitive nuclear DNAs from Phytophthora infestans. Current Genetics 22, 107-15.

Goodwin SB, Schneider RE, Fry WE, 1995c. Use of cellulose acetate electrophoresis for rapid identification of allozyme genotypes of Phytophthora infestans. Plant Disease 79, 11815.

Goodwin SB, Smart CD, Sandrock RW, Deahl KL, Punja ZK, Fry WE, 1998. Genetic change within populations of Phytophthora infestans in the United States and Canada during 1994-96: role of migration and recombination. Phytopathology $88,939-49$.

Goodwin SB, Spielman LJ, Matuszak JM, Bergeron SN, Fry WE, 1992b. Clonal diversity and genetic differentiation of Phytophthora infestans populations in northern and central Mexico. Phytopathology 82, 955-61.

Goodwin SB, Sujkowski LS, Dyer AT, Fry BA, Fry WE, 1995a. Direct detection of gene flow and probable sexual reproduction of Phytophthora infestans in northern North America. Phytopathology 85, 473-9.

Goodwin SB, Sujkowski LS, Fry WE, 1995b. Rapid evolution of pathogenicity within clonal lineages of the potato late blight disease fungus. Phytopathology 85, 669-76.

Griffith GW, Shaw DS, 1998. Polymorphisms in Phytophthora infestans: four mitochondrial haplotypes are detected after PCR amplification of DNA from pure cultures or from host lesions. Applied and Environmental Microbiology 64, 4007-14.

Harper GL, Maclean N, Goulson D, 2003. Microsatellite markers to assess the influence of population size, isolation and demographic change on the genetic structure of the UK butterfly Polyommatus bellargus. Molecular Ecology 12, 3349-57.

Hartl DL, Clark AG, 1997. Principles of Population Genetics, 3rd edn. Sunderland, Hermansen A, Hannukkala A, Naerstad RH, Brurberg MB, 2000. Variation in populations of Phytophthora infestans in Finland and Norway: mating type, metalaxyl resistance and virulence phenotype. Plant Pathology 49, 11-22.

Hurst L, 2002. The Ka/Ks ratio: diagnosing the form of sequence evolution. Trends in Genetics 18, 486-7.

Hussain S, 2003. Diagnostics and Epidemiology of Phytophthora infestans, the Cause of Late Blight of Potato. SCRI, Dundee, UK: University of Abertay, PhD Thesis.

Ishii H, Noguchi K, Tomita Y, Umemoto S, Nishimura $\mathrm{K}, 1999$. Occurrence of strobilurin resistance in powdery mildew and downy mildew on cucumber. Annual Phytopathological

Society of Japan 65, 655 (Abstract).

Jorde PE, Palm S, Ryman N, 1999. Estimating genetic drift and effective population size from temporal shifts in dominant gene marker frequencies. Molecular Ecology 8, 1171-8.

Judelson HS, 1997a. Expression and inheritance of sexual preference and selfing potential in Phytophthora infestans. Fungal Genetics and 
Biology 21, 188-97.

Judelson HS, 1997b. The genetics and biology of Phytophthora infestans: modern approaches to a historical challenge. Fungal Genetics and Biology 22, 65-76.

Judelson HS, Roberts S, 1999. Multiple loci determining insensitivity to phenylamide fungicides in Phytophthora infestans. Phytopathology 89, 754-60.

Judelson HS, Spielman LJ, Shattock RC, 1995. Genetic mapping and non-Mendelian segregation of mating type loci in the oomycete, Phytophthora infestans. Genetics 141, 503-12.

Judelson HS, Yang GE, 1998. Recombinant pathways in Phytophthora infestans: polyploidy resulting from aberrant sexual development and zoospore mediated heterokaryosis. Mycological Research $102,1245-53$.

Kamoun S, 2003. Molecular genetics of pathogenic oomycetes. Eukaryotic Cell 2, 191-9.

Kamoun S, Hraber P, Sobral B, Nuss D, Govers F, 1999. Initial assessement of gene diversity for the oomycete pathogen Phytophthora infestans based on expressed sequences. Fungal Genetics and Biology 28, 94-106.

Kato M, Mizubuti ES, Goodwin SB, Fry WE, 1997. Sensitivity to protectant fungicides and pathogenic fitness of clonal lineages of Phytophthora infestans in the United States. Phytopathology 87, 973-8.

Kaye C, Milazzo J, Rozenfeld S, Lebrun M, Tharreau D, 2003. The development of simple sequence repeat markers for Magnaporthe grisea and their integration into an established genetic linkage map. Fungal Genetics and Biology 40, 207-14.

Kessel GJT, Jansen DM, Schepers HTAM, Wander JGN, Spits HG, Flier WG, 2003. WURBlight: an experimental decision support module linking fungicide dosage to late blight resistance. In: Schepers HTAM, Westerdijk CE, eds. Proceedings of the Seventh Workshop of a European Network for Development of an Integrated Control Strategy of Potato Late Blight, Poznan, Poland, October 2002. Wageningen, the Netherlands: Applied Plant Research, 31-8. (PPO-Special Report No. 9.).

Knapova G, Gisi U, 2002. Phenotypic and genotypic structure of Phytophthora infestans populations on potato and tomato in France and Switzerland. Plant Pathology 51, 641-53.

Knapova G, Tenzer I, Gessler C, Gisi U, 2001. Characterization of Phytophthora infestans from potato and tomato with molecular markers. Proceedings of the 5th Congress of the European Foundation for Plant Pathology (Biodiversity in Plant Pathology). Taormina, Italy: SIVP, 6-9.
Kohn MH, Pelz H, Wayne RK, 2000. Natural selection mapping of the warfarin-resistance gene. Proceedings of the National Academy of Science, USA 97, 7911-5.

Koufopanou V, Burt A, Taylor JW, 1997. Concordance of gene genealogies reveals reproductive isolation in the pathogenic fungus Coccidioides immitis. Proceedings of the National Academy of Science, USA 94, 5478-82.

Lam ST, 2001. Phytophthora genomics consortium. Phytopathology 91 (Suppl.), S158.

Lebreton L, Andrivon D, 1998. French isolates of Phytophthora infestans from potato and tomato differ in their phenotype and genotype. European Journal of Plant Pathology 104, 583-94.

Lebreton L, Lucas J, Andrivon D, 1999. Aggressiveness and competitive fitness of Phytophthora infestans isolates collected from potato and tomato in France. Phytopathology 89, 679-86.

van der Lee T, De Witte I, Drenth A, Alfonso C, Govers F, 1997. AFLP linkage map of the oomycete Phytophthora infestans. Fungal Genetics and Biology 21, 278-91.

Lee TY, Mizubuti E, Fry WE, 1999. Genetics of metalaxyl resistance in Phytophthora infestans. Fungal Genetics and Biology 26, 118-30.

van der Lee T, van Testa A, 'T, Klooster J, van den Berg-Velthuis G, Govers F, 2001. Chromosomal deletion in isolates of Phytophthora infestans correlates with virulence on R3, R10 and R11 potato lines. Molecular Plant-Microbe Interactions, 14, 1444-52.

Legard DE, Lee TY, Fry WE, 1995. Pathogenic specialization in Phytophthora infestans: aggressiveness on tomato. Phytopathology 85, 1356-61.

Li Y, Korol AB, Fahima T, Beiles A, Nevo E, 2002. Microsatellites: genomic distribution, putative functions and mutational mechanisms: a review. Molecular Ecology 11, 2453-65.

Luikart G, England PR, Tallmon D, Jordan S, Taberlet $P, 2003$. The power and promise of population genomics: from genotyping to genome typing. Nature Reviews Genetics 4, 981-4.

Maggioni R, Rogers AD, Maclean N, 2003. Population structure of Litopenaeus schmitti (Decapoda: Penaeidae) from the Brazilian coast identified using six polymorphic microsatellite loci. Molecular Ecology 12, 3213-7.

Malcolmson JF, 1969. Races of Phytophthora infestans occurring in Great Britain. Transactions of the British Mycological Society 53, 417-23.

Malcolmson JF, Black W, 1966. New R genes in Solanum demissum Lindl. and their complementary races of Phytophthora infestans 
(Mont.) de Bary. Euphytica 15, 199-203.

McDermott JM, McDonald BA, 1993. Gene flow in plant pathosystems. Annual Review of Phytopathology 31, 353-73.

McDonald BA, Linde C, 2002. Pathogen population genetics, evolutionary potential and durable resistance. Annual Review of Phytopathology 40, 349-79.

Milbourne D, Meyer R, Bradshaw JE, Baird E, Bonar N, Provan J, Powell W, Waugh R, 1997. Comparison of PCRbased marker systems for the analysis of genetic relationships in cultivated potato. Molecular Breeding 3, 127-36.

Milgroom MG, Fry WE, 1997. Contributions of population genetics to plant disease epidemiology and management. Advances in Botanical Research 24, 1-30.

Mizubuti ESG, Fry WE, 1998. Temperature effects on developmental stages of isolates from three clonal lineages of Phytophthora infestans. Phytopathology 88, 837-43.

Ordoñez ME, Hohl HR, Velasco JA, Ramon MP, Oyarzun PJ, Smart CD, Fry WE, Forbes GA, Erselius LJ, 2000. A novel population of Phytophthora, similar to $P$. infestans, attacks wild Solanum species in Ecuador. Phytopathology 90, 197-202.

Paquin B, Laforest MJ, Forget L, Roewer I, Wang Z, Longcore J, Lang BF, 1997. The fungal mitochondrial genome project: evolution of fungal mitochondrial genomes and their gene expression. Current Genetics 31, 380-95.

Peters RD, Platt HW, Hall R, 1998. Changes in race structure of Canadian populations of Phytophthora infestans based on specific virulence to selected potato clones. Potato Research

41, 355-79.

Pipe ND, Azcoitia V, Shaw DS, 2000. Self-fertility in Phytophthora infestans: heterokaryons segregate several phenotypes. Mycological Research 104, 676-80.

Posada D, Crandall KA, Templeton AR, 2000. GEODIS: a program for the nested cladistic analysis of the geographical distribution of genetic haplotypes. Molecular Ecology

9, 487-8.

Punja ZK, Förster H, Cunningham I, Coffey MD, 1998. Genotypes of the late blight pathogen (Phytophthora infestans) in British Columbia and other regions of Canada during 1993-97. Canadian Journal of Plant Pathology 20, 274-8.

Purvis AL, Pipe ND, Day JP, Shattock RC, Shaw DS, Assinder SJ, 2001. AFLP and RFLP (RG57) fingerprints can give conflicting evidence about the relatedness of isolates of Phytophthora infestans. Mycological Research 105, 1321-30.

Randall TA, Judelson HS, 1999. Construction of a bacterial artificial chrosmosome library of Phytophthora infestans and transformation of clones into $P$. infestans. Fungal Genetics and Biology 28, 160-70.

Reis A, Smart CD, Fry WE, Maffia LA, Mizubuti ESG, 2003. Characterization of isolates of Phytophthora infestans from Southern and Southeastern Brazil from 1998 to 2000. Plant

Disease 97, 896-900.

Ristaino JB, Groves CT, Parra GR, 2001. PCR amplification of the Irish potato famine pathogen from historic specimens. Nature 411, 695-7.

Shattock RC, 1988. Studies on the inheritance of resistance to metalaxyl in Phytophthora infestans. Plant Pathology 37, 4-11.

Shattock RC, Janssen BD, Whitbread R, Shaw DS, 1977. An interpretation of the frequencies of host-specific phenotypes of Phytophthora infestans in North Wales. Annals of Applied Biology 86, 249-60.

Shattock RC, Shaw DS, 1975. Mutants of Phytophthora infestans resistant to, and dependent upon, antibiotics. Transactions of the British Mycological Society 64, 29-41.

Shattock RC, Tooley PW, Fry WE, 1986. The genetics of Phytophthora infestans: determination of recombination, segregation and selfing by isozyme analysis. Phytopathology 76, 410-3.

Shaw DS, 1991. Genetics. In: Ingram DS, Williams $\mathrm{PH}$, eds. Advances in Plant Pathology 7. London, UK: Academic Press, 131-70.

Shaw DS, Shattock RC, 1991. Genetics of Phytophthora infestans: the Mendelian approach. In: Lucas JA, Shattock RC, Shaw DS, Cooke LR, eds. Phytophthora. Cambridge, UK: Cambridge University Press, 218-30.

Smart CD, Willmann MR, Mayton H, Mizubuti ESG, Sandrock RW, Muldoon AE, Fry WE, 1998. Self-fertility in two clonal lineages of Phytophthora infestans. Fungal Genetics and Biology 25, 134-42.

Spielman LJ, McMaster BJ, Fry WE, 1992. Relationships among measurements of fitness and disease severity in Phytophthora infestans. Plant Pathology 41, 317-24.

Spielman LJ, Sweigard JA, Shattock RC, Fry WE, 1990. The genetics of Phytophthora infestans: segregation of allozyme markers in F2 and backcross progeny and the inheritance of virulence against potato resistance genes $R 2$ and $R 4$ in F1 progeny. Experimental Mycology 14, 57-69.

Stephens M, Smith NJ, Donnelly P, 2001. A new statistical method for haplotype reconstruction 
from population data. American Journal of Human Genetics 68, 978-89.

Stewart HE, 1990. The effect of plant age and inoculums concentration on expression of major gene resistance to Phytophthora infestans in detached potato leaflets. Mycological Research 94, 823-6.

Sujkowski LS, Goodwin SB, Dyer AT, Fry WE, 1994. Increased genotypic diversity via migration and possible occurrence of sexual reproduction of Phytophthora infestans in Poland.

Phytopathology 84, 201-7.

Tang S, Kishore VK, Knapp SJ, 2003. PCRmultiplexes for a genome-wide framework of simple sequence repeat marker loci in cultivated sunflower. Theoretical and Applied Genetics 107, 6-19.

Templeton AR, 2004. Statistical phylogeography: methods of evaluating and minimizing inference errors. Molecular Ecology 13, 789-810.

Tian D, Traw MB, Chen JQ, Kreitman M, Bergelson J, 2003. Fitness costs of R-gene-mediated resistance in Arabidopsis thaliana. Nature 423, 74-7.

Tooley PW, Fry WE, Villerreal Gonzalez MJ, 1985. Isozyme characterization of sexual and asexual Phytophthora infestans populations. Journal of Heredity 76, 431-5.

Tooley PW, Therrien CD, 1991. Variation in ploidy in Phytophthora infestans. In: Lucas JA, Shattock RC, Shaw DS, Cooke LR, eds. Phytophthora. Cambridge, UK: Cambridge University Press, 205-17.

Torto TA, Li SA, Styer A, Huitema E, Testa A, Gow NAR, van West P, Kamoun S, 2003. EST mining and functional expression assays identify extracellular effector proteins from the plant pathogen Phytophthora. Genome Research 13, 1675-85.

Trognitz BR, 1998. Inheritance of resistance in potato to lesion expansion and sporulation by Phytophthora infestans. Plant Pathology 47, 712-22.

Van der Hoorn RAL, De Wit PJGM, Joosten MHAJ,
2002. Balancing selection favors guarding resistance proteins. Trends in Plant Science 7, 67-71.

Vos P, Hoger R, Bleeker M, Reijans M, van der Lee T, Hornes M, Frijters A, Pot J, Peleman J, Kuiper M, Zabeau M, 1 995. AFLP: a new technique for DNA fingerprinting. Nucleic Acids Research 23, 4407-14.

Wallin JM, Holt CL, Kazaruk KD, Nguyen TH, Walsh PS, 2002. Constructing universal multiplex PCR systems for comparative genotyping. Journal of Forensic Science 47, 52-65.

Wangsomboondee T, Groves CT, Shoemaker PB, Cubeta MA, Ristaino JB, 2002. Phytophthora infestans populations from tomato and potato in North Carolina differ in genetic diversity and structure. Phytopathology 92, 1189-95.

Wattier RAM, Gathercole LL, Assinder SJ, Gliddon CJ, Deahl KL, Shaw DS, Mills DI, 2003. Sequence variation of intergenic mitochondrial DNA spacers (mtDNA-IGS) of Phytophthora infestans (Oomycetes) and related species. Molecular Ecology Notes 3, 136-8.

Waugh M, Hraber P, Weller J, Wu Y, Chen G, Inman J, Kiphart D, Sobral B, 2000. The Phytophthora genome initiative database: informatics and analysis for distributed pathogenomic research. Nucleic Acids Research 28, 87-90.

Whisson SC, van der Lee T, Bryan GJ, Waugh R, Govers F, Birch PRJ, 2001. Physical mapping across an avirulence locus of Phytophthora infestans using a highly representative, largeinsert bacterial artificial chromosome library. Molecular Genetics and Genomics 266, 289-95.

Whittaker SL, Assinder SJ, Shaw DS, 1994. Inheritance of mitochondrial DNA in Phytophthora infestans. Mycological Research 98, 569-75.

Zwankhuizen MJ, Govers F, Zadoks JC, 2000. Inoculum sources and genotypic diversity of Phytophthora infestans in Southern Flevoland, the Netherlands. European Journal of Plant Pathology 106, 667-80.

\section{How to cite this article:}

Pranamika Sharma, Anil Kumar Jena, Rimi Deuri, Surya Prakash Singh and Sangeeta Sarmah. 2018. Review on Molecular Epidemiology in Relation to Devastating Late Blight Pathogen, $P$. infestans, de Bary. Int.J.Curr.Microbiol.App.Sci. 7(08): 4651-4685.

doi: https://doi.org/10.20546/ijcmas.2018.708.491 